\title{
APPLICATION OF MULTIPLE-CRITERIA DECISION-MAKING TECHNIQUES AND APPROACHES TO EVALUATING OF SERVICE QUALITY: A SYSTEMATIC REVIEW OF THE LITERATURE
}

\author{
Abbas MARDANI ${ }^{1}$, Ahmad JUSOH ${ }^{2}$, Edmundas Kazimieras ZAVADSKAS ${ }^{3}$, \\ Zainab KHALIFAH ${ }^{4}$, Khalil MD NOR ${ }^{5}$ \\ 1,2,4,5Faculty of Management, Universiti Teknologi Malaysia (UTM), \\ Skudai, Johor, 81310, Malaysia. \\ ${ }^{3}$ Research Institute of Smart Building Technologies, Vilnius Gediminas Technical University, \\ Sauletekio al. 11, LT-10223 Vilnius, Lithuania \\ E-mails:1'mabbas3@live.utm.my; 2ahmadj@management.utm.my; \\ 3edmundas.zavadskas@vgtu.lt (correspondingauthor); \\ 4zainab@management.utm.my; ${ }^{5}$ m-khalil@utm.my \\ Recaived 24 July 2015; accepted 14 September 2015
}

\begin{abstract}
The main purpose of this paper is to present a systematic review of multiplecriteria decision-making (MCDM) techniques used in the assessment of service quality. This study reviewed a total of 79 articles from 51 journals, published from 2001 to 2015. Articles were classified into 10 application areas and scopes. Furthermore, articles were categorised based on an author, year, application area, the nationality of the author, Ttechnique, a number of criteria, research purpose, gap and research problem, results and outcome. The best criteria were determined in each article. The results of this study revealed that more papers on MCDM were published in 2011 than in any other year. Integrated techniques, analytic hierarchy process (AHP) and fuzzy AHP methods, were ranked as first and second methods in use, respectively. Finally, the airline industry was ranked as the first application area, in which previous studies applied MCDM techniques for the evaluation of the service quality. This research contributes to the existing literature on the service quality and MCDM. The research outputs are valuable to academics scholars and leaders of organisations and industries in the field of service quality evaluation.
\end{abstract}

Keywords: AHP, airline industry, decision making, literature review, multiple-criteria decision making, service quality, TOPSIS.

JEL Classification C44, L25, M1, M10, M11.

\section{Introduction}

The steadily growing amount of literature on service quality covers a variety of interpretations and implementations. At the time of decision making, decision makers attempt to select the best solution. Indeed, a truly best solution can be obtained from a single criterion, which is taken into consideration. In most actual decision-making 
procedures, it is insufficient to make a decision based on one criterion only; rather, a number of inconsistent and non-commensurable objectives must be taken into account. MCDM is applied in situations, which have contradictory criteria to help individuals make decisions in accordance with their preference (Bogetoft, Pruzan 1997). MCDM is associated with the division of a complicated difficulty into smaller parts. Once decisions are made, and issues related to smaller parts of the problem are considered, the parts of the problem are reconstructed to represent an inclusive view of the decision makers (DMs) (Dodgson et al. 2009). Meanwhile, the issue of service quality can be measured according to different qualitative and quantitative criteria; the MCDM techniques are appropriate for the assessment of expected service quality. There are many ways to measure the service quality, such as statistical approaches, analysis of multicriteria satisfaction for benchmarking, AHP, VIKOR (VIsekriterijumska optimizacija i KOmpromisno Resenje), fuzzy AHP, Preference Ranking Organisation Method for Enrichment Evaluation (PROMETHEE), and Technique for Order Preference by Similarity to Ideal Solution (TOPSIS).

This literature review identified a substantial body of literature on the application of MCDM techniques and approaches used to address service quality problems. During this review, we attempted to outline a number of major MCDM approaches and techniques offered throughout the years and ways various approaches and techniques have been used for service quality problems in various industries such as the airline industry, the tourism industry, the healthcare industry, etc. The examples were selected to give an extensive overview of all approaches and techniques that have been applied to service quality problems. This article also evaluates the most important advantages of various approaches and techniques and the difficulties they might face. Furthermore, this article attempts to review those selected articles based on various perspectives, such as an author, year, application area, the nationality of the author, technique and approach, a number of criteria, scope, research purpose, gap and research problem, results and outcomes. The best criteria are determined in each article. Finally, this study argues that MCDM is practical for solving problems related to the service quality and involving multiple resources; however, this type of problems has not yet been examined in any MCDM review study.

\section{Literature review}

\subsection{Service quality, MCDM and its application areas}

Delivering, building, understanding and maintaining better service quality are the major concerns of every industry today. Service quality expectation was used to describe service predictions, an ideal standard, an attribute of importance, and customer evaluation of the service quality (Tseng 2009a). The main purpose of evaluating the service quality is to measure service performance, diagnose service problems, manage service delivery, and provide the optimal service for all customers (Li 1997). Many methods can be used to study the service quality. MCDM techniques have been formulated to evaluate the service quality in various application areas such as the airline industry, websites and 
Internet services, tourism and the hospitality industry, the healthcare industry, other transportation industries, the manufacturing industry, the banking sector, the education sector and service organisations. MCDM techniques were extensively applied in ranking a limited amount of decision alternatives characterised through multiple, typically conflicting attributes; those techniques are mainly suitable for the decision problems where it is actually more significant and necessary to attain a cardinal preference or ranking of the substitutes in service quality issues. In this section of the paper, we attempted to show the important role of MCDM techniques in 10 areas of application for the service quality. In recent years, MCDM techniques were used in different application areas by other scholars for the evaluation of the service quality issue.

\subsubsection{Airline industry and service quality}

The airline industry plays an important role for the service sector itself as well as contributes significantly to other industries through the ability to transport passengers to their required locations all over the globe (Rhoades, Waguespack Jr 2008). Generally, competitive policies of airlines focus on the price, service matters, and service quality. The level and quality of service can affect the competitive advantage of an airline through client support, and with this comes a market portion and, eventually, effectiveness (Ozment, Morash 1994). The service quality of airline companies can be influenced by the concerns and gratification of customers and relates to a number of important issues concerning charges and productivity of the companies. Generally, the decision-making procedure for the assessment of the service quality is considered one of the several necessities with indefinite circumstances and should be considered concurrently. Several precision-based MCDM approaches for assessing the service quality in aircraft manufacturing, and choosing substitutions were improved, with most of the substitutes associated with the synthesized rankings. These investigations were related to the doubt and/or imprecise numeric values of decision data and the subjectiveness of human behaviour. According to findings of Table 1, 18 of previous studies used MCDM techniques in the airline industry. Other information details, such as the number of criteria, resarch purpose, gap and research problem, results and outcome and the best criteria for this category, are presented in Table 1.

\subsubsection{Websites and Internet services, MCDM and the service quality}

The rise of the Internet has changed the decision-making behaviour of consumers, and information sharing in social media has become an important reference for consumers making purchasing decisions (Elzinga et al. 2009). In recent years, social media and other types of Internet communities have become mainstream all over the world, with increasing numbers of individuals and businesses getting involved in social media activities (Edelman 2010). Therefore, Internet service quality must also be considered. MCDM is capable of dealing with multiple dimensions of evaluation problems and is a rapidly developing area of operational research and management science (Shee, Wang 2008). The complete MCDM process involves the following basic elements: criteria, preference structure, alternatives and performance values. While the final decision will be made based on the performance of alternatives, evaluation criteria and preference structure are key influential factors and should be prepared in advance. 


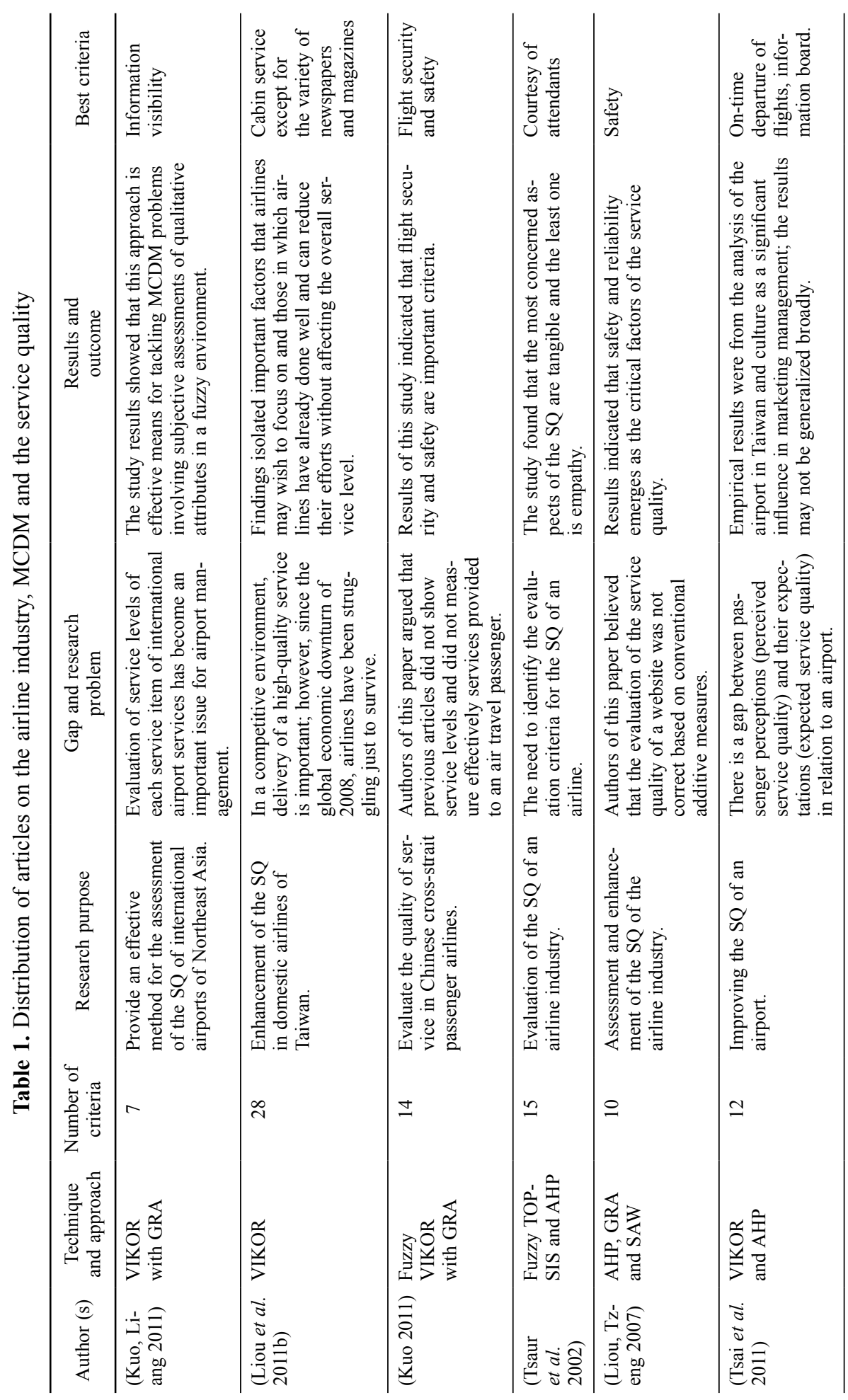


A. Mardani et al. Application of multiple-criteria decision-making techniques and approaches ...

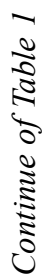

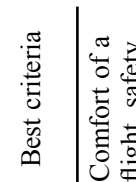

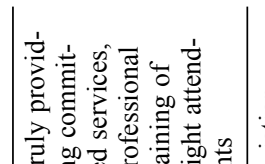

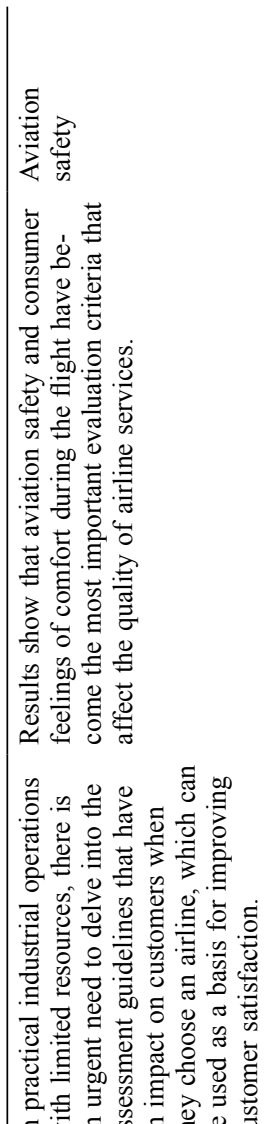

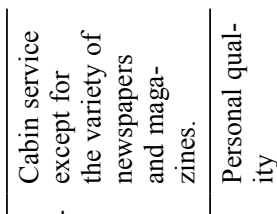

范

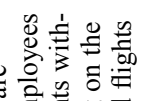

.

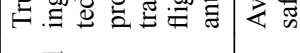

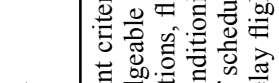

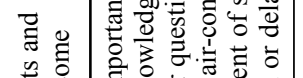

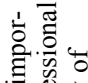

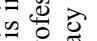

=

艺苛

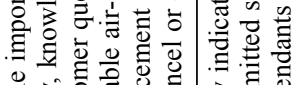

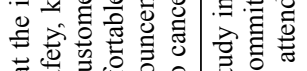

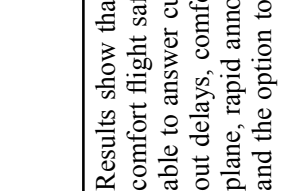

की

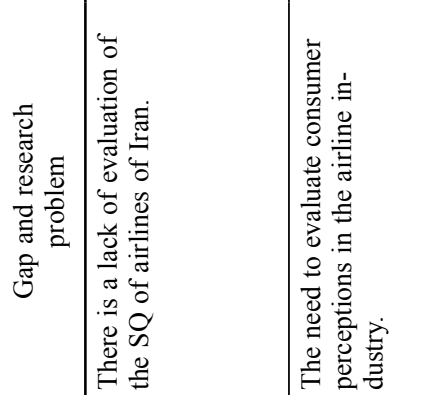

फै융

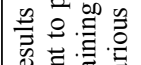

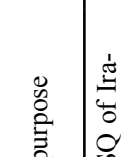

胥焉

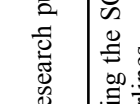

$\approx$

4

管.

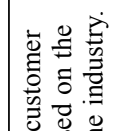

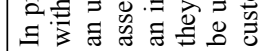

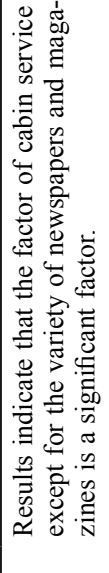

.

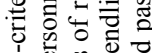

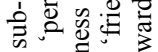

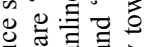

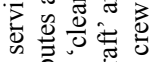

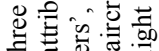

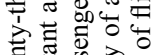

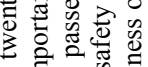

의용

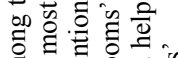

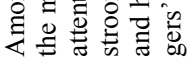

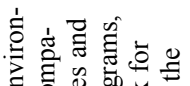

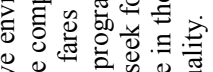

$\geq$.

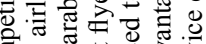

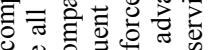

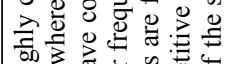

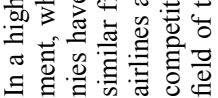

.

空.

寻

范

을

急蛋离

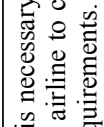




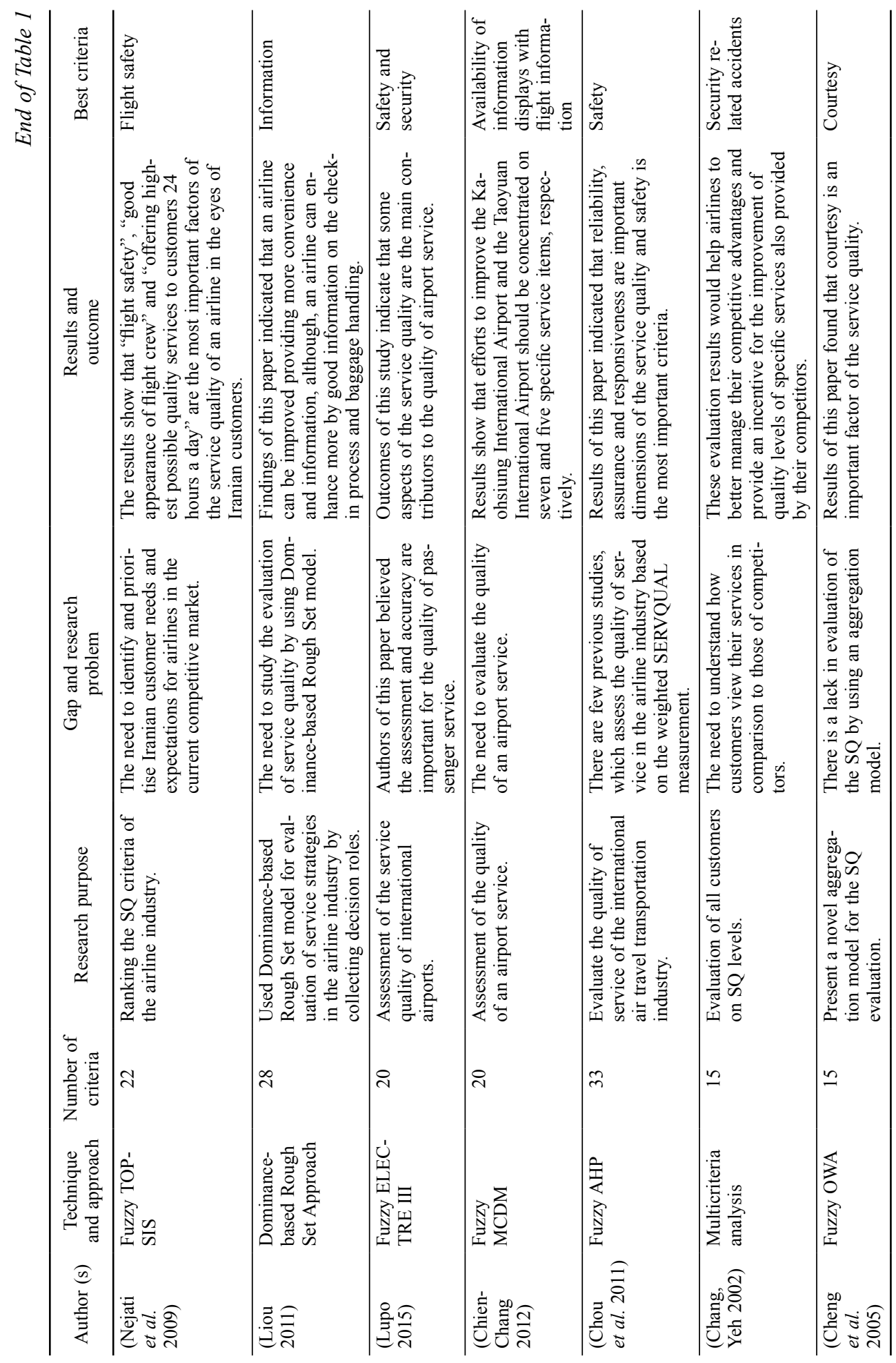


In order to obtain the evaluation criteria and preference structure, such as the quality of Internet service, hierarchical analysis must be carried out (Shee, Wang 2008). Over the past decades, there has been a large number of refined MCDM methods developed for the evaluation of service quality and Internet service and they differ from each other in the required quality and quantity of additional information, the methodology used, the user-friendliness, the sensitivity tools used, and the mathematical properties they verify (Zavadskas, Turskis 2011). Based on findings provided in Table 2, 16 researchers applied MCDM techniques for the evaluation of the quality of services offered on websites and Internet. Other information, such as the number of criteria, research purpose, gap and research problem, results and outcome, and the best criteria for this category, is presented in Table 2.

\subsubsection{Tourism and hospitality industry, MCDM and the service quality}

The assessment of the service quality in the hotel industry is considered an on-going procedure, which needs constant monitoring for maintaining high stages of the service quality through several service areas (qualities). The assessment must be founded on a comparative procedure, which permits managers to recognise areas of service development or deterioration below some previously set standard of performance. Therefore, the assessment consequences might be applied by CEOs as means for benchmarking of several service areas. Identifying the most insignificant factors that impact on service quality is considered important. It can help CEOs of hotels focus on issues having the maximum weight and find the best strategy for the development of the hotel efficiency. The question is how to assess the relative significance of these factors. They may be measured as a multiple-attribute decision-making problem. At present, many MCDM methods for assessing the quality of hotels are promoted by public authorities and private companies. Previous studies used the MCDM technique for evaluation of the service quality in the tourism and hospitality industry. Based on outcomes of Table 3, 13 previous studies used MCDM techniques for the assessment of the service quality in the tourism and hospitality industry. Other information, such as the number of criteria, the research purpose, gap and research problem, results and outcome, and the best criteria for this category are presented in Table 3 .

\subsubsection{Healthcare industry, MCDM and the service quality}

In the healthcare industry, the service quality dates back to the mid-19th century. Faced with continuous competitive pressure, a growing number of medical providers have realised that being able to provide good healthcare service quality is the most important factor in ensuring the future success (Min et al. 1997). For patients, quality and effectiveness of hospitals are two major concerns when seeking for healthcare services. If patients are not satisfied with the service quality provided by a hospital, they will seek for healthcare services elsewhere. Hospitals, therefore, have to enhance their healthcare quality and efficiency in order to retain their existing patients and attract new ones (Chang et al. 2011). To manage the challenges of globalisation and intensive competition successfully, hospital managers must pay more attention to the expectation of the service quality. 


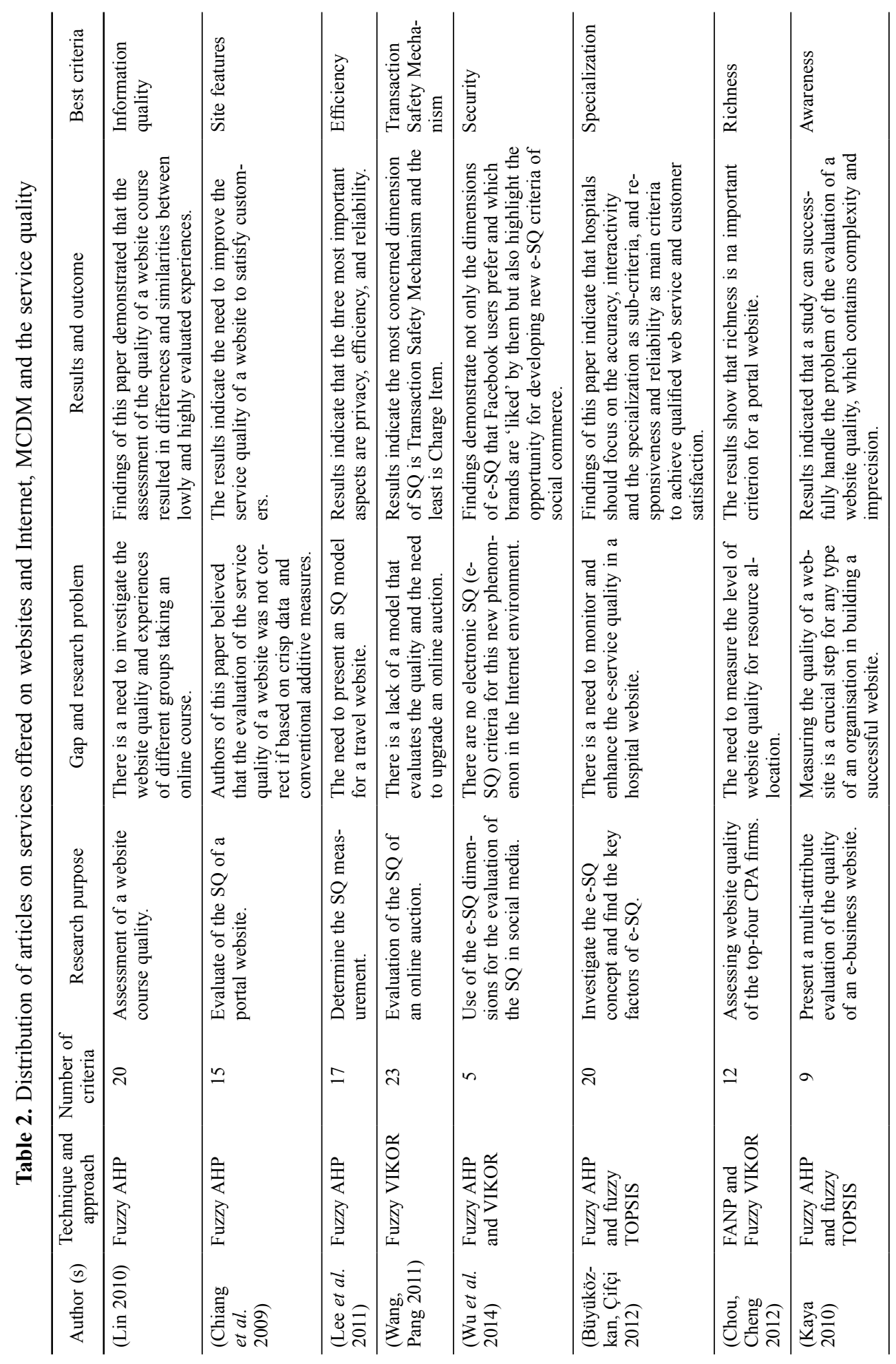


A. Mardani et al. Application of multiple-criteria decision-making techniques and approaches ...

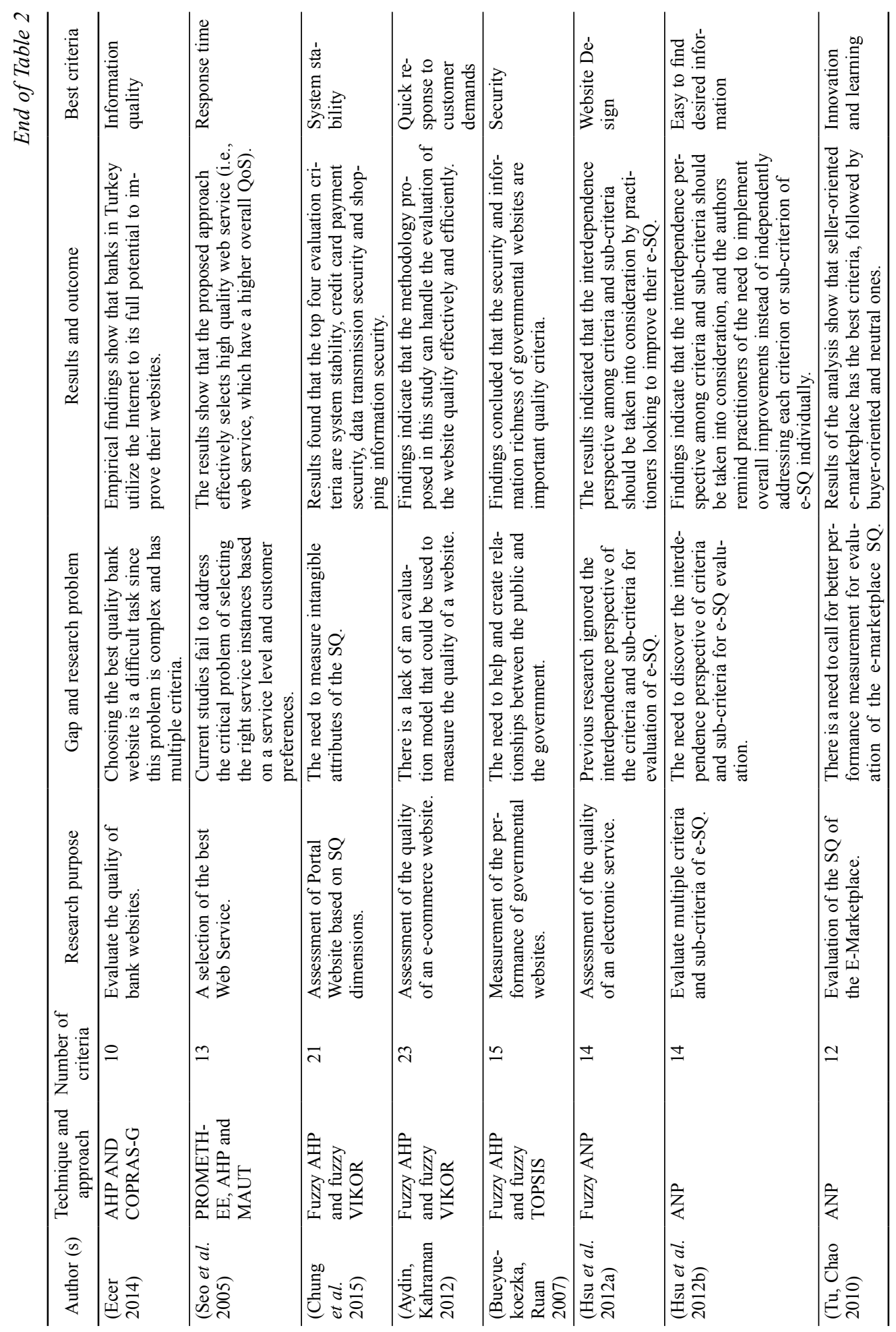




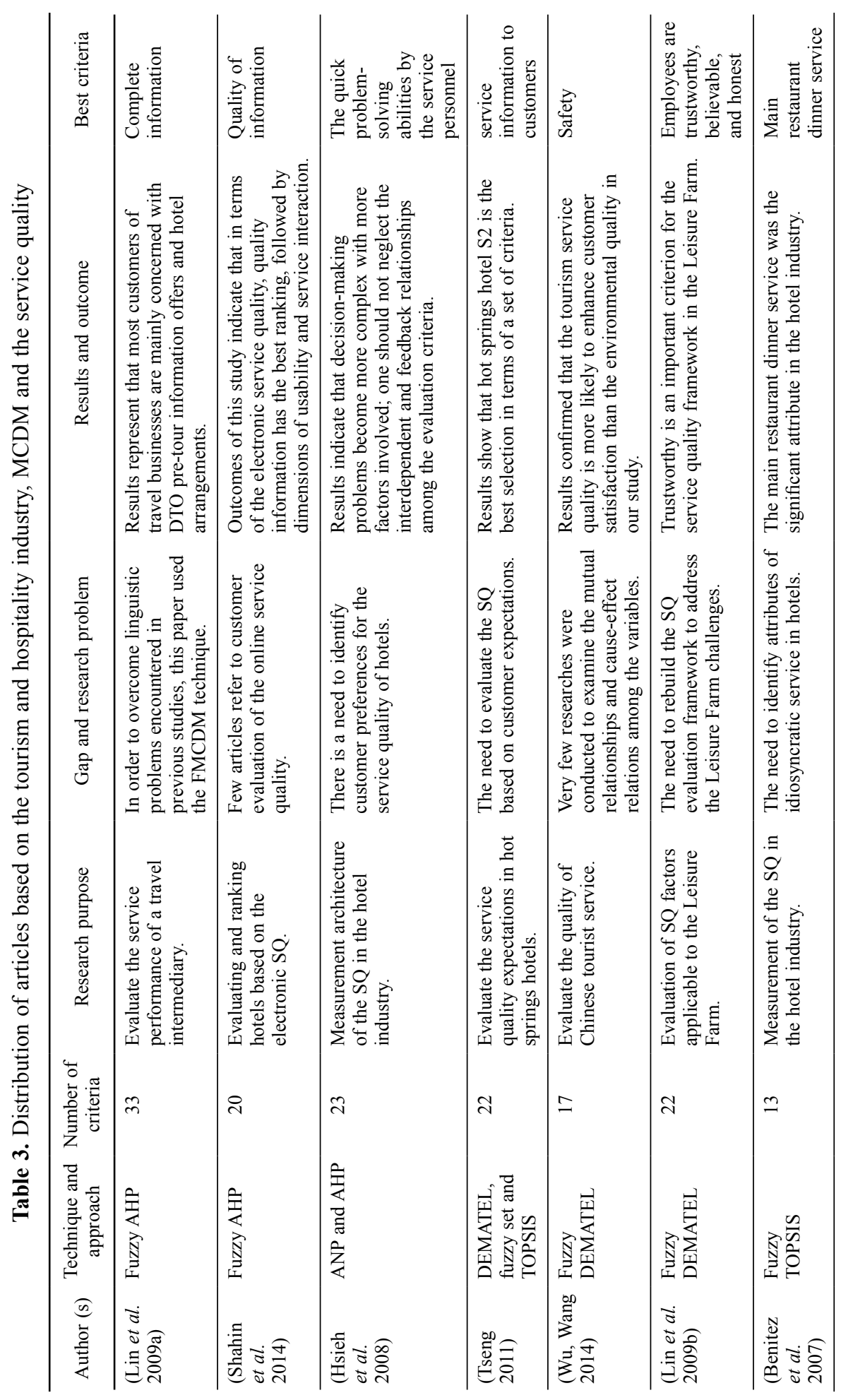


A. Mardani et al. Application of multiple-criteria decision-making techniques and approaches ...

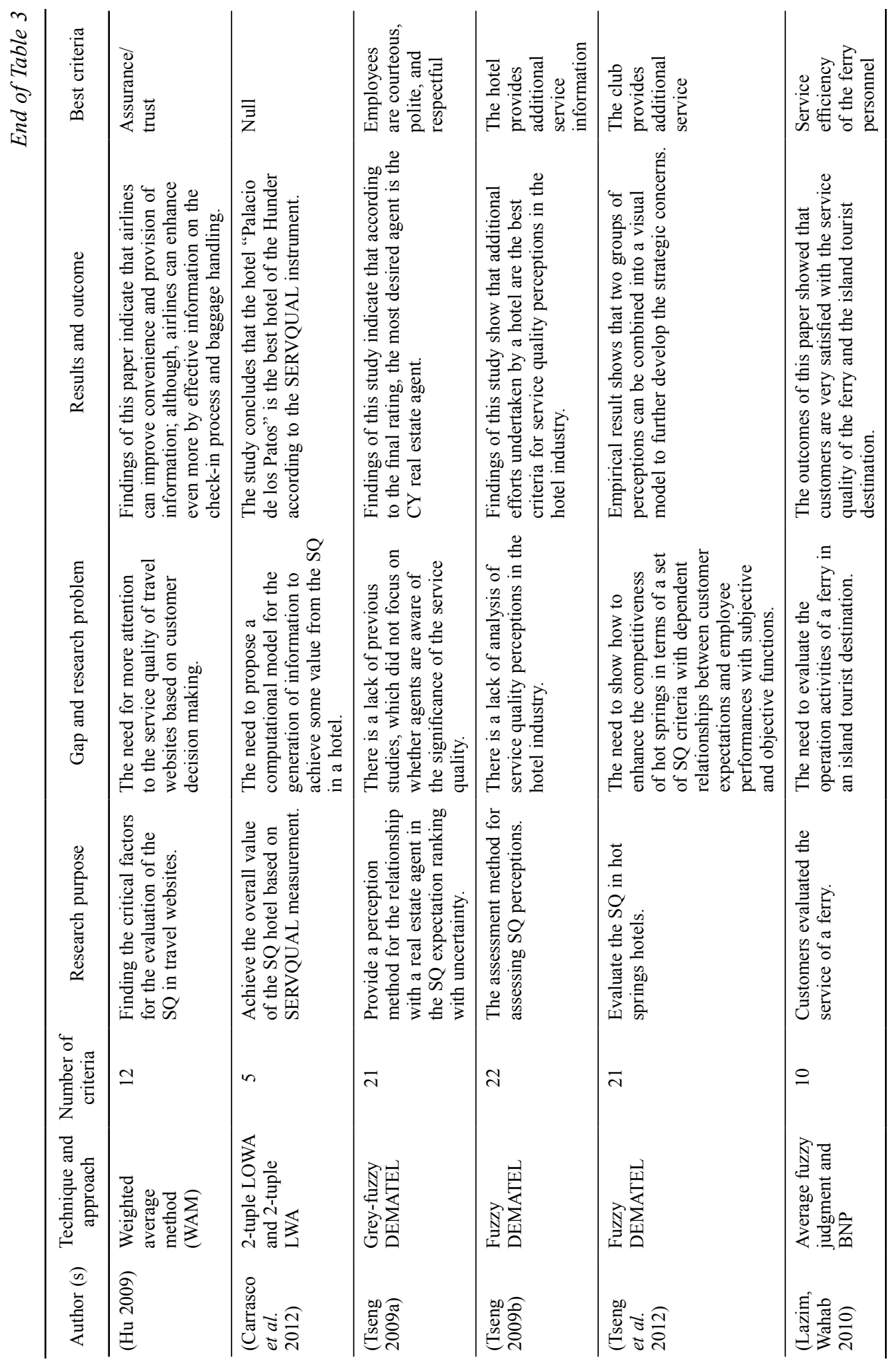


Therefore, how to closely meet the needs of patients and how to assess the service quality of patients have become critical challenges for hospital administrators (Teng et al. 2007). Based on the service industry classification, a hospital is a service industry with the characteristics of contacting with people directly, communicating with people frequently, and providing customised and professional medical services (Shieh et al. 2010). Although the service quality of a hospital has been in development for several years, evaluating the service quality expectation is as vital as to ascertain whether hospitals are well aware of the importance of the service quality. Since the service quality of a hospital can be measured according to different qualitative and quantitative criteria, the MCDM approach is suitable for evaluating the expectation of the service quality of a hospital. There are many ways to measure the service quality, such as statistical approaches, multi-criteria satisfaction analysis for benchmarking analysis, AHP, VIKOR, fuzzy AHP, PROMETHEE, and TOPSIS. According to finding of Table 4, seven of previous papers used MCDM techniques for evaluation of the service quality in the healthcare industry. Other information, such as the number of criteria, research purpose, gap and research problem, results and outcome, and the best criteria for this category, are presented in Table 4.

\subsubsection{Other transportation industries, MCDM and the service quality}

The evaluation of the service quality of transportation systems is considered important for the development of productivity, gaining income and improving client gratification. This includes evaluation of several issues associated with the service quality, for instance, efficacy, reliability, safety, ease, etc. The usually applied multi-criteria decisionmaking methods for the evaluation of the service quality of public transit schemes are founded on weighted scoring. In multi-criteria decision-making methods, the substitute is assessed against multiple weighted standards, and an aggregate performance score is identified. If the substitute performs over a pre-defined threshold limit, the service quality is believed to be perfect. The substitute with the maximum score is selected as the best substitute. Yeh et al. (2000) proposed a fuzzy MCDM method for performance assessment of bus firms. Tsaur et al. (2002) applied the MCDM model to accomplish that the most significant qualities of air transport services are politeness, safety and ease. According to the SERVQUAL and fuzzy TOPSIS, Yedla and Shrestha (2003) offered a multi-criteria method according to the AHP to select the alternative choices for ecologically sustainable transport system in Delhi. Outcomes of Table 5 show that five of previous studies applied MCDM techniques for the evaluation of the service quality in transportation industries. Some other information, such as the number of criteria, research purpose, gap and research problem, results and outcome and the best criteria for this category, are presented in Table 5. 
A. Mardani et al. Application of multiple-criteria decision-making techniques and approaches ...

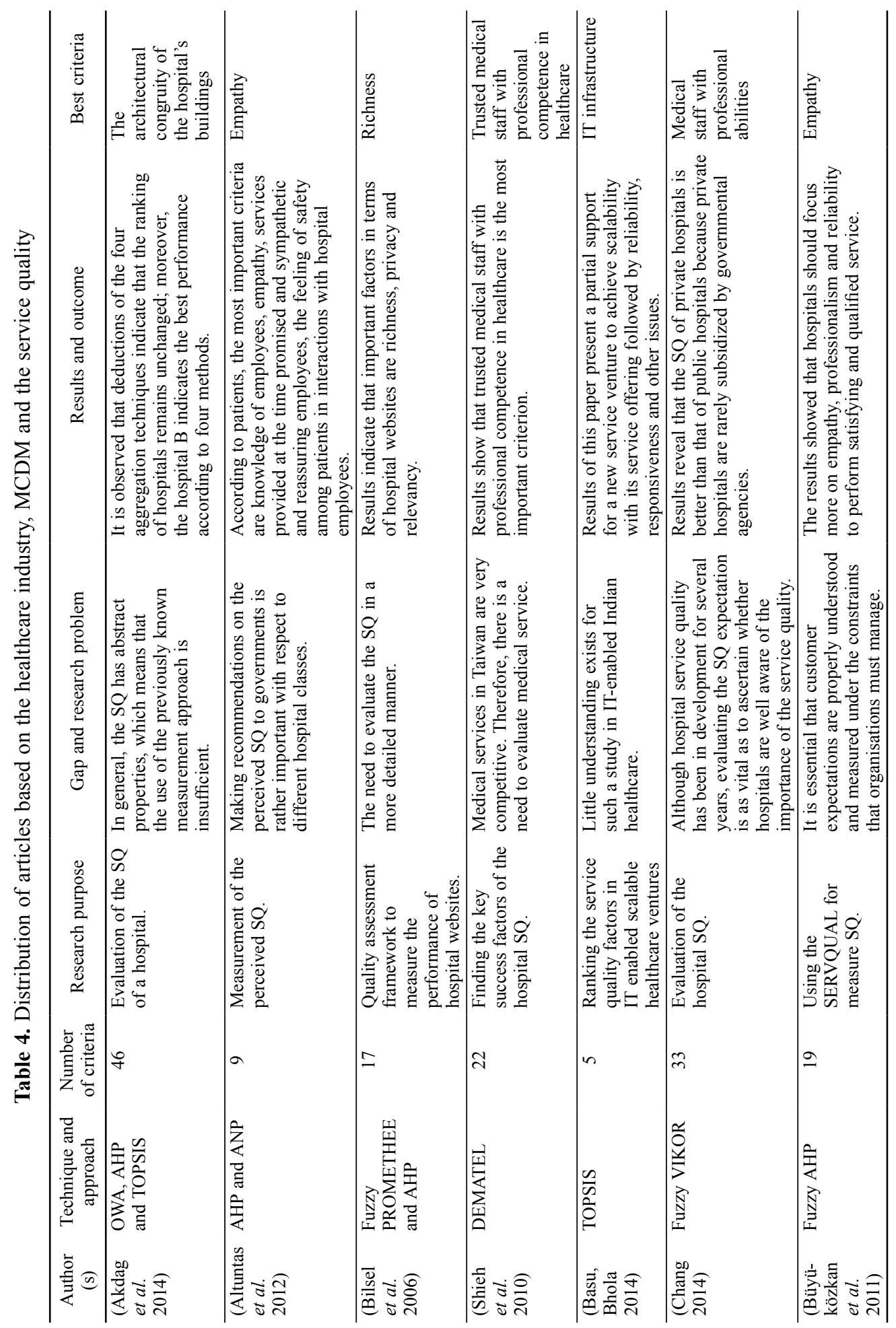




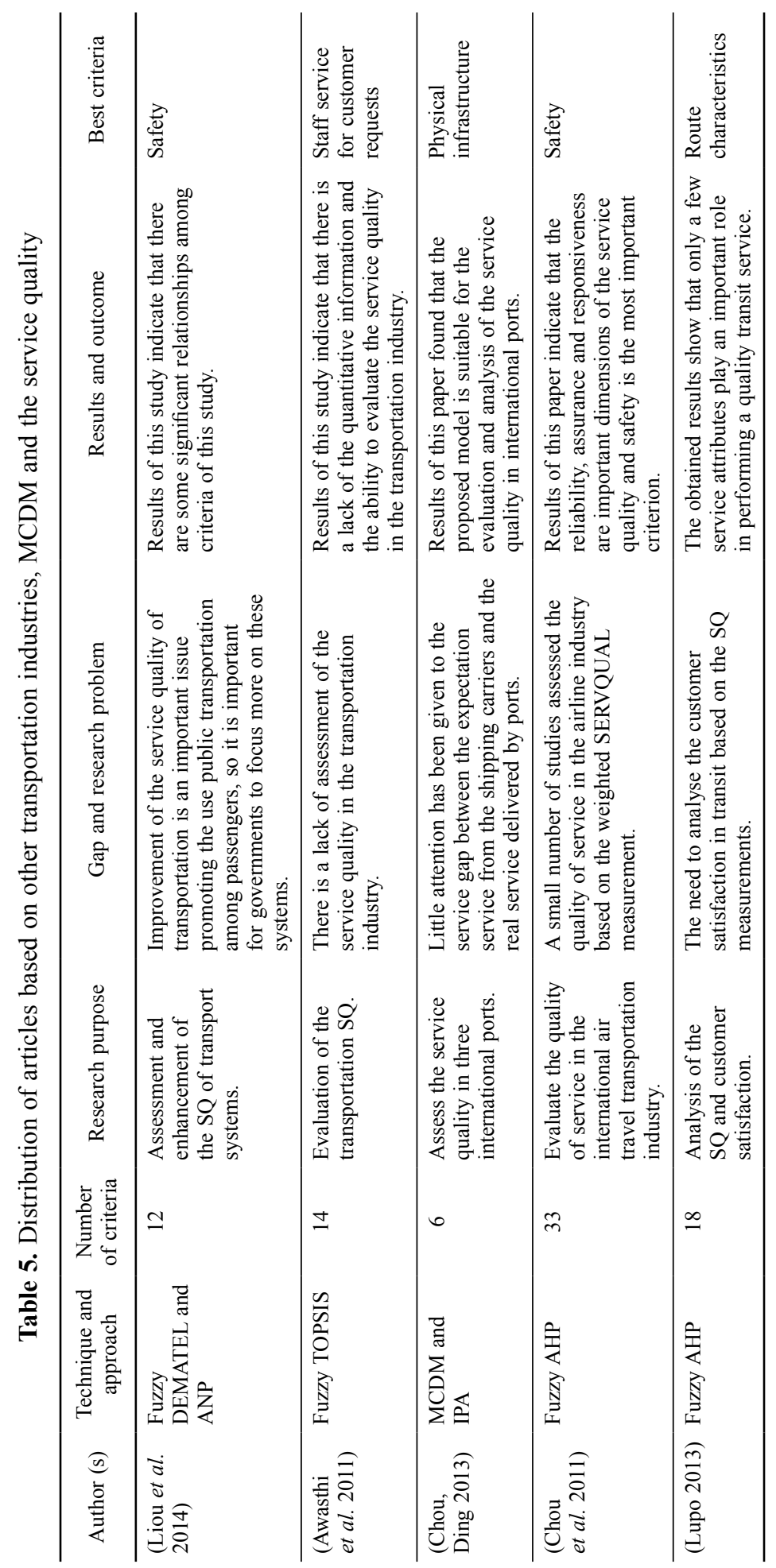




\subsubsection{Manufacturing industry, MCDM and the service quality}

The tangible result regarding the manufacturing businesses is considered a physical product. This is a billable product that they sell. Even then, the service quality is considered significant, as it contains sensitivity to client requirements, concerning the defective product and upkeep. Likewise, adding service might be a strategic solution for companies aiming to add value for the client, and grow their business in a competitive marketplace. For companies that cannot compete on production costs alone, adding better client service has a probability of becoming a competitive advantage (Souiden, Pons 2009). According to Table 6, findings showed that five of researchers used MCDM techniques such as AHP, fuzzy AHP, etc. for evaluation of the service quality in manufacturing industries. Some other information, such as the number of criteria, research purpose, gap and research problem, results and outcome, determine the best criteria for this category, are presented in Table 6 .

\subsubsection{Banking sector, MCDM and the service quality}

During the recent years, banks have become ever more concerned with understanding that the service related decisions of clients is not merely affected by value, but also by the service provision available after the distribution of the service (Agnihothri et al. 2002). The operative distribution of high-quality service may help and sustain long-term association with clients. Banking has been functioning in a comparatively steady setting for several years. However, today the businesses are intensely associated with violent and deregulated competition conditions. Each bank should understand how to enter a marketplace and preserve the competitive advantage (Zineldin 2002). These days, no enterprise can succeed without attracting sufficient clients. Based on Rust and Oliver (1993), the service quality, "is considered a subjective notion, by nature, which means that knowing how the client thinks regarding the service quality is considered vital for the operative management". It is, therefore, the client's insight into the service quality a company delivers that is dominant and eventually has competitive consequences. Lastly, bankers must focus on the service quality for pleasing customers as it is obvious that the service quality has a superior and stronger positive effect on client gratification if to compare the Islamic banks with conservative banks of Pakistan (Ahmad et al. 2010). Ferreira et al. (2012) proposed a framework for evaluating the performance in five bank branches in Portugal. Results of this study suggested that the application of cognitive maps identified some omitted criteria, which might affect possible attractiveness. Results of Table 7 represented that four of previous scholars used MCDM techniques such as fuzzy TOPSIS, Fuzzy GA-based and WAM etc. for assessing the service quality in the banking sector. Some other information, such as the number of criteria, research purpose, gap and research problem, results and outcome, and the best criteria for this category, are presented in Table 7. 


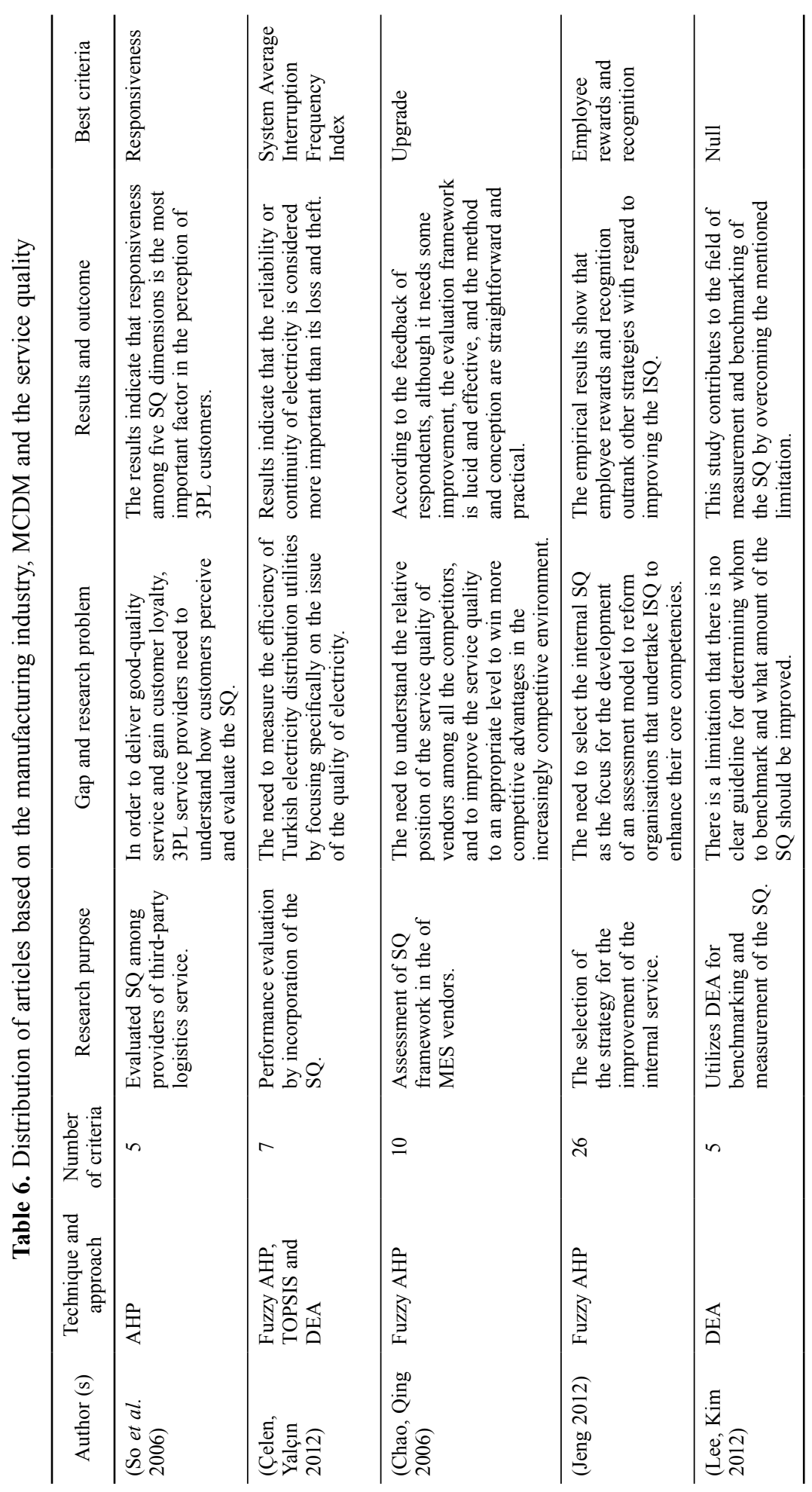




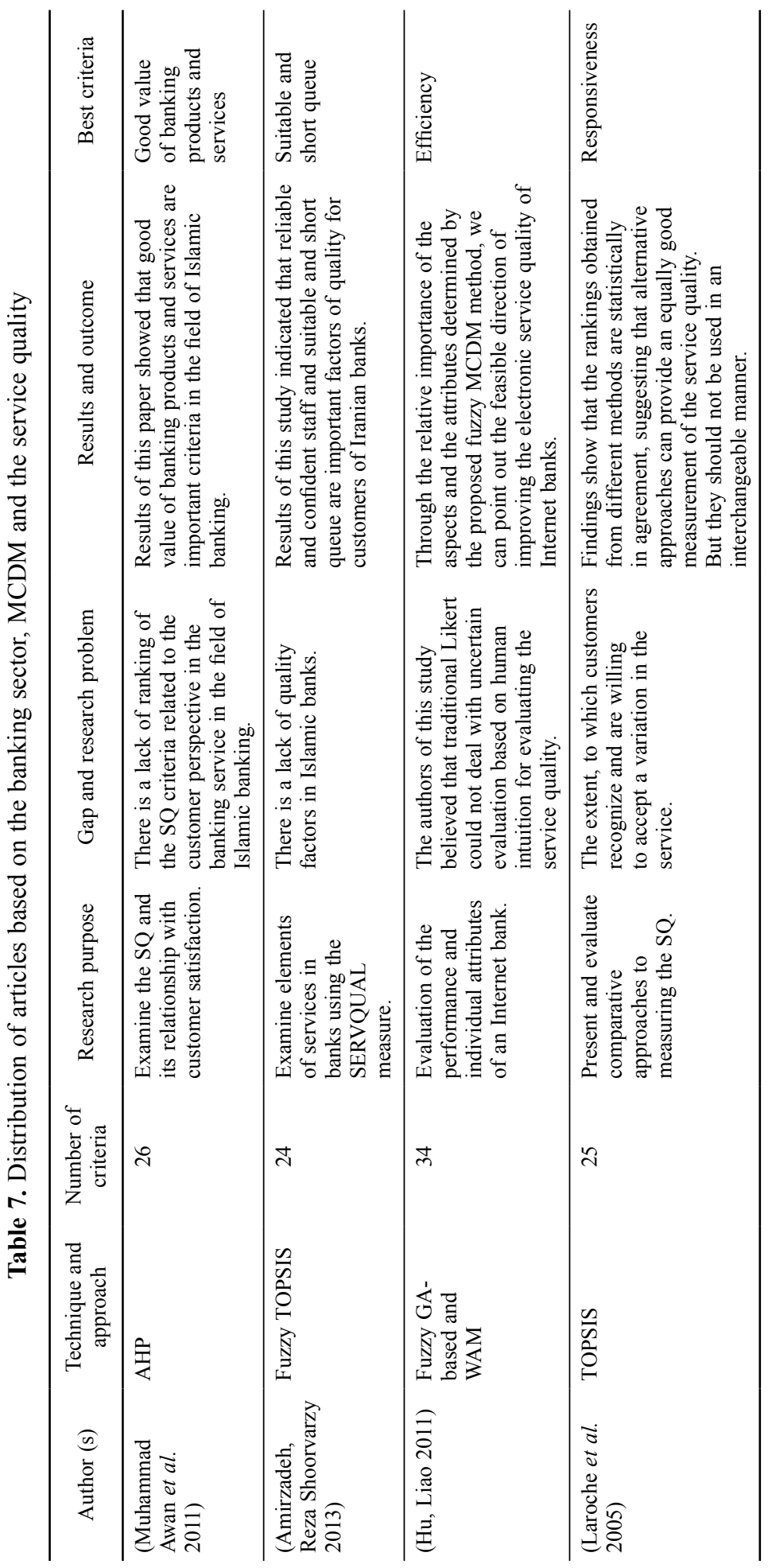




\subsubsection{Education sector, MCDM and the service quality}

Universities have understood the importance of providing high-quality education as their product and have been driven by competition to evaluate the superiority of their amenities, to redefine their product and to measure client gratification in ways, which are familiar to service marketing experts. Universities have understood that their longterm survival relies on how good their services are and that superiority sets one university apart from the rest (Aly, Akpovi 2001). Education amenities are frequently intangible and problematic to be measured, as the consequence is reproduced in the transformation of persons in their knowledge, their features, and their behaviour. Consequently, there is no universally accepted description of quality, which can be used for the development of the education sector. Consequently, businesses desiring to develop profitability are recommended to screen and make developments to improve their service quality on a constant basis (Gerrard, Cunningham 2005). Specialists and researchers are interested in precisely gauging the service quality to know its necessary subjects better and, eventually, create approaches for developing the quality to obtain competitive advantages (Lassar et al. 2000). As a serious measure of organisational performance, the service quality remains at the forefront of both the marketing literature in general, and the service marketing literature in particular (Jensen, Markland 1996). Based on results of Table 8, four previous studies used MCDM for the evaluation of the service quality in the education sector. Some other information, such as the number of criteria, research purpose, gap and research problem, results and outcome, and the best criteria for this category, are presented in Table 8.

\subsubsection{Service organisations, MCDM and the service quality}

The service quality is usually a critical concern for most companies of the service industry. The need for high-quality service has always been an important issue for many organisations. Business growth and survival are the two important effects of customers on an enterprise because they are the fundamental construct of an enterprise, especially a customer-oriented enterprise. Therefore, main issues concerning the service industry are to improve the service quality and to satisfy customer demands in the competitive business environment. The activity of a service organisation in relation to all characteristics and scopes of the service quality can vary. Abdullah and Ling (2012) presented a new approach to the evaluation of the service quality in insurance companies by applying the interval-valued intuitionistic fuzzy entropy measure. It was found that PCF Insurance was evaluated as the best vehicle insurance company in providing the service quality to customers. Chiang and Yu (2011) improved the service quality of a real estate broker by integrating TOPSIS and AHP. Results of this study found the weights of four criteria being $0.263,0.429,0.119$ and 0.189 for square footage of the home, the sales price, the distance to the workplace and the lot size of the property, respectively. According to Table 9, findings showed that five of earlier studies employed MCDM techniques such as AHP, fuzzy TOPSIS etc. for assessing the service quality in service organisations. Other information, such as the number of criteria, research purpose, gap and research problem, results and outcome, and the best criteria for this category, are presented in Table 9. 
Table 8. Distribution of articles based on the education sector, MCDM and the service quality

\begin{tabular}{|c|c|c|c|c|c|c|}
\hline $\begin{array}{l}\text { Author } \\
\text { (s) }\end{array}$ & $\begin{array}{l}\text { Technique } \\
\text { and } \\
\text { approach }\end{array}$ & $\begin{array}{l}\text { Number } \\
\text { of } \\
\text { criteria }\end{array}$ & $\begin{array}{l}\text { Research } \\
\text { purpose }\end{array}$ & $\begin{array}{l}\text { Gap and research } \\
\text { problem }\end{array}$ & Results and outcome & $\begin{array}{c}\text { Best } \\
\text { criteria }\end{array}$ \\
\hline $\begin{array}{l}\text { (Tsinidou } \\
\text { et al. } \\
2010)\end{array}$ & AHP & 40 & $\begin{array}{l}\text { Finding the } \\
\text { quality de- } \\
\text { terminants } \\
\text { for educa- } \\
\text { tion ser- } \\
\text { vices. }\end{array}$ & $\begin{array}{l}\text { The need to de- } \\
\text { velop insights into } \\
\text { comparative evalu- } \\
\text { ations of quality } \\
\text { determinants as } \\
\text { they are perceived } \\
\text { by students. }\end{array}$ & $\begin{array}{l}\text { The findings concern- } \\
\text { ing the career prospects } \\
\text { group demonstrate that } \\
\text { all students, irrespective } \\
\text { of their department, con- } \\
\text { sider career prospects as } \\
\text { a top priority, followed } \\
\text { by opportunities for } \\
\text { postgraduate education } \\
\text { and the links of the insti- } \\
\text { tution with businesses. }\end{array}$ & $\begin{array}{l}\text { Communi- } \\
\text { cation }\end{array}$ \\
\hline $\begin{array}{l}\text { (Huang } \\
\text { et al. } \\
\text { 2012) }\end{array}$ & $\begin{array}{l}\text { DEMATEL, } \\
\text { GRA and } \\
\text { ANP }\end{array}$ & 6 & $\begin{array}{l}\text { Improve the } \\
\text { SQ for sat- } \\
\text { isfaction of } \\
\text { customers }\end{array}$ & $\begin{array}{l}\text { The need for a } \\
\text { model that can } \\
\text { be used to close } \\
\text { the SQ gap, fulfil } \\
\text { customer expecta- } \\
\text { tions and maximise } \\
\text { profits. }\end{array}$ & $\begin{array}{l}\text { Results found that the } \\
\text { expertise in dynamic } \\
\text { capacity management } \\
\text { and new education and } \\
\text { training should be the } \\
\text { most important strategies } \\
\text { for the service quality } \\
\text { enhancement. }\end{array}$ & $\begin{array}{l}\text { Scalable } \\
\text { storage }\end{array}$ \\
\hline $\begin{array}{l}\text { (Jamal, } \\
\text { Sayyadi } \\
\text { Tooranloo } \\
\text { 2009) }\end{array}$ & $\begin{array}{l}\text { Fuzzy } \\
\text { TOPSIS }\end{array}$ & 56 & $\begin{array}{l}\text { Ranking } \\
\text { of the SQ } \\
\text { criteria of a } \\
\text { library. }\end{array}$ & $\begin{array}{l}\text { The need to iden- } \\
\text { tify new ways to } \\
\text { achieve quality } \\
\text { and to monitor its } \\
\text { attainment are the } \\
\text { current challenges } \\
\text { for libraries. }\end{array}$ & $\begin{array}{l}\text { The results show that } \\
\text { there is no equal impor- } \\
\text { tance between library } \\
\text { service quality indica- } \\
\text { tors. }\end{array}$ & $\begin{array}{l}\text { Enabling } \\
\text { customers } \\
\text { to find in- } \\
\text { formation } \\
24 \text { hours a } \\
\text { day }\end{array}$ \\
\hline $\begin{array}{l}\text { (Tsai } \\
\text { et al. } \\
2008)\end{array}$ & Fuzzy AHP & 5 & $\begin{array}{l}\text { Investigate } \\
\text { integrated } \\
\text { SERV- } \\
\text { QUAL } \\
\text { dimensions. }\end{array}$ & $\begin{array}{l}\text { Results obtained } \\
\text { from previous } \\
\text { studies cannot } \\
\text { identify the dimen- } \\
\text { sion, which is more } \\
\text { important and } \\
\text { effective for depart- } \\
\text { ment stores. }\end{array}$ & $\begin{array}{l}\text { The results of this work } \\
\text { determined that using the } \\
\text { fuzzy set theory method } \\
\text { can provide the best } \\
\text { suggestions for depart- } \\
\text { ment store managers in } \\
\text { enhancing the service } \\
\text { quality. }\end{array}$ & Tangibles \\
\hline
\end{tabular}

Table 9. Distribution of articles based on the education sector, MCDM and the service quality

\begin{tabular}{|c|c|c|c|c|c|c|}
\hline $\begin{array}{l}\text { Author } \\
\text { (s) }\end{array}$ & $\begin{array}{l}\text { Technique } \\
\text { and } \\
\text { approach }\end{array}$ & $\begin{array}{c}\text { Number } \\
\text { of } \\
\text { criteria }\end{array}$ & Research purpose & $\begin{array}{l}\text { Gap and research } \\
\text { problem }\end{array}$ & $\begin{array}{l}\text { Results and } \\
\text { outcome }\end{array}$ & $\begin{array}{l}\text { Best } \\
\text { criteria }\end{array}$ \\
\hline $\begin{array}{l}\text { (Chiang, } \\
\text { Yu 2011) }\end{array}$ & $\begin{array}{l}\text { TOPSIS and } \\
\text { AHP }\end{array}$ & 4 & $\begin{array}{l}\text { Improve the SQ of a } \\
\text { real estate broker. }\end{array}$ & $\begin{array}{l}\text { The need to enhance } \\
\text { the SQ of brokers, } \\
\text { because they play } \\
\text { an important role in } \\
\text { providing useful and } \\
\text { satisfactory informa- } \\
\text { tion to the real estate } \\
\text { buyers. }\end{array}$ & $\begin{array}{l}\text { Results found that } \\
\text { weights of four } \\
\text { criteria: } 0.263 \text {, } \\
0.429,0.119 \text { and } \\
0.189 \text { for square } \\
\text { footage of the } \\
\text { home, the sales } \\
\text { price, the distance } \\
\text { to the workplace } \\
\text { and the lot size } \\
\text { of the property, } \\
\text { respectively. }\end{array}$ & $\begin{array}{l}\text { The sales } \\
\text { price }\end{array}$ \\
\hline
\end{tabular}


End of Table 9

\begin{tabular}{|c|c|c|c|c|c|c|}
\hline $\begin{array}{l}\text { Author } \\
\text { (s) }\end{array}$ & $\begin{array}{l}\text { Technique } \\
\text { and } \\
\text { approach }\end{array}$ & $\begin{array}{l}\text { Number } \\
\text { of } \\
\text { criteria }\end{array}$ & Research purpose & $\begin{array}{l}\text { Gap and research } \\
\text { problem }\end{array}$ & $\begin{array}{l}\text { Results and } \\
\text { outcome }\end{array}$ & $\begin{array}{l}\text { Best } \\
\text { criteria }\end{array}$ \\
\hline $\begin{array}{l}\text { (Choi } \\
\text { et al. } \\
2007)\end{array}$ & $\begin{array}{l}\text { Fuzzy TOP- } \\
\text { SIS }\end{array}$ & 6 & $\begin{array}{l}\text { Evaluate the mobile } \\
\text { service quality }\end{array}$ & $\begin{array}{l}\text { Due to the intrinsic } \\
\text { subjectivity and in- } \\
\text { visibility of custom- } \\
\text { er perception, con- } \\
\text { ventional approaches } \\
\text { are subjected to } \\
\text { some shortcom- } \\
\text { ings in measuring } \\
\text { the mobile service } \\
\text { quality. }\end{array}$ & $\begin{array}{l}\text { The quality of } \\
\text { the device was } \\
\text { evaluated as a high } \\
\text { quality dimen- } \\
\text { sion of the mobile } \\
\text { service in Korea. }\end{array}$ & $\begin{array}{l}\text { Security } \\
\text { quality }\end{array}$ \\
\hline $\begin{array}{l}\text { (Chen } \\
2001)\end{array}$ & $\begin{array}{l}\text { Fuzzy GM- } \\
\text { CDM }\end{array}$ & 5 & $\begin{array}{l}\text { Effective measure- } \\
\text { ment of the SQ. }\end{array}$ & $\begin{array}{l}\text { The need to measure } \\
\text { the SQ dimensions } \\
\text { based on customer } \\
\text { views. }\end{array}$ & $\begin{array}{l}\text { According to re- } \\
\text { sults of this paper, } \\
\text { one can determine } \\
\text { not only the } \\
\text { level of the service } \\
\text { quality but also } \\
\text { the ranking order } \\
\text { of all evaluation } \\
\text { organisations. }\end{array}$ & Null \\
\hline $\begin{array}{l}\text { (Abdul- } \\
\text { lah, Ling } \\
\text { 2012) }\end{array}$ & $\begin{array}{l}\text { Fuzzy en- } \\
\text { tropy }\end{array}$ & 21 & $\begin{array}{l}\text { Present a new ap- } \\
\text { proach to the evalu- } \\
\text { ation of the service } \\
\text { quality in insurance } \\
\text { companies by ap- } \\
\text { plying the interval- } \\
\text { valued intuitionistic } \\
\text { fuzzy entropy } \\
\text { measure. }\end{array}$ & $\begin{array}{l}\text { There is a small } \\
\text { number of studies } \\
\text { that evaluate the } \\
\text { service quality by } \\
\text { using the interval- } \\
\text { valued intuitionistic } \\
\text { fuzzy set. }\end{array}$ & $\begin{array}{l}\text { It was found that } \\
\text { PCF Insurance } \\
\text { was evaluated as } \\
\text { the best vehicle } \\
\text { insurance company } \\
\text { in providing the } \\
\text { service quality to } \\
\text { customers. }\end{array}$ & Insurance \\
\hline
\end{tabular}

\subsubsection{Other areas, MCDM and the service quality}

In this section, researchers focus on some previous studies that use other techniques and approaches for the evaluation of the service quality in various and different application areas and scopes, such as the airline industry, the healthcare industry, tourism and the hospitality industry, banking and education sectors, websites and Internet services, etc. Chen et al. (2009) evaluated a model of service quality based on linguistic options and TOPSIS technique. Results of this paper develop an information system based on the linguistic TOPSIS method to deal with the service quality evaluation problem. Lin and Lin (2013) supposed that previous investigation has focused on the attendee viewpoint. This investigation categorised exhibitor viewpoints on the service quality of a host organisation. Results of this investigation showed that exhibition marketing was the most significant criteria to exhibitors, counting Internet exposure and inviting foreign consumers. Based on results in Table 10, three of previous studies have applied various techniques and methods for the evaluation of the service quality in different application areas and scopes. Other information details, such as the number of criteria, research purpose, gap and research problem, results and outcome, and the best criteria for this category, are presented in Table 10. 
Table 10. Distribution of articles based on other areas, MCDM and the service quality

\begin{tabular}{|c|c|c|c|c|c|c|}
\hline $\begin{array}{c}\text { Author } \\
\text { (s) }\end{array}$ & $\begin{array}{l}\text { Technique } \\
\text { and } \\
\text { approach }\end{array}$ & $\begin{array}{l}\text { Number of } \\
\text { criteria }\end{array}$ & $\begin{array}{l}\text { Research } \\
\text { purpose }\end{array}$ & $\begin{array}{l}\text { Gap and research } \\
\text { problem }\end{array}$ & Results and outcome & $\begin{array}{l}\text { Best } \\
\text { criteria }\end{array}$ \\
\hline $\begin{array}{l}\text { (Lin } \\
2011)\end{array}$ & $\begin{array}{l}\text { DEMATEL, } \\
\text { ANP and } \\
\text { VIKOR }\end{array}$ & 5 & $\begin{array}{l}\text { Selection } \\
\text { and } \\
\text { evaluation } \\
\text { of the } \\
\text { critical } \\
\text { factor of } \\
\text { the SQ. }\end{array}$ & $\begin{array}{l}\text { There is a problem } \\
\text { in the decision of } \\
\text { service quality for } \\
\text { shopping platform } \\
\text { services in Taiwan. }\end{array}$ & $\begin{array}{l}\text { Results reveal that } \\
\text { customers treat the "service } \\
\text { feature and quality" and } \\
\text { the "customer benefit and } \\
\text { appreciation" as important } \\
\text { aspects. "Classification } \\
\text { and searching" and } \\
\text { "recommendation and } \\
\text { limited information" are } \\
\text { not as important. }\end{array}$ & $\begin{array}{l}\text { Service } \\
\text { feature } \\
\text { and } \\
\text { quality }\end{array}$ \\
\hline $\begin{array}{l}\text { (C. T. } \\
\text { Lin, } \\
\text { C. W. } \\
\text { Lin } \\
\text { 2013) }\end{array}$ & AHP & 6 & $\begin{array}{l}\text { Examine } \\
\text { the quality } \\
\text { of service } \\
\text { provided } \\
\text { to an } \\
\text { exhibitor. }\end{array}$ & $\begin{array}{l}\text { Prior research } \\
\text { focused on the } \\
\text { attendee perspective. } \\
\text { This study } \\
\text { classified exhibitor } \\
\text { perspectives on the } \\
\text { service quality of the } \\
\text { host organisation. }\end{array}$ & $\begin{array}{l}\text { Results showed that } \\
\text { exhibition marketing } \\
\text { was the most important } \\
\text { criterion to exhibitors, } \\
\text { including Internet exposure } \\
\text { and inviting specific } \\
\text { overseas buyers. }\end{array}$ & $\begin{array}{l}\text { Internet } \\
\text { exposure }\end{array}$ \\
\hline $\begin{array}{l}\text { (Chen } \\
\text { et al. } \\
2009 \text { ) }\end{array}$ & TOPSIS & Null & $\begin{array}{l}\text { Evaluate } \\
\text { the Model } \\
\text { of SQ } \\
\text { based on } \\
\text { linguistic } \\
\text { options. }\end{array}$ & $\begin{array}{l}\text { It is not easy } \\
\text { to evaluate the } \\
\text { quality of a service } \\
\text { alternative directly. } \\
\text { Therefore, the } \\
\text { need exists to use } \\
\text { a linguistic method } \\
\text { to design a service } \\
\text { quality evaluation } \\
\text { system. }\end{array}$ & $\begin{array}{l}\text { Develop an information } \\
\text { system based on the } \\
\text { linguistic TOPSIS method } \\
\text { to deal with the problem } \\
\text { of the evaluation of the } \\
\text { service quality. }\end{array}$ & Null \\
\hline
\end{tabular}

\section{Area of application and scope}

In recent decades, continued research of MCDM revealed many areas, to which it can be applied. MCDM provides strong decision-making methods in domains where a selection of the best alternative is highly complex. The main purpose of this review paper is to identify various applications in and approaches to the service quality and to suggest approaches that can be used most robustly and effectively to identify the best criteria. MCDM has been applied to many domains of the service quality evaluation in various industries, organisations, companies, etc. The MCDM method helps to choose best alternatives where many criteria exist. The best alternative can be obtained by analysing different scopes and weights for the criteria and the selection of the optimum ones using any MCDM techniques. This survey shows a comprehensive view of the development of various methods of MCDM and its applications in the evaluation of the service quality. In total, 79 articles were classified into 10 application areas and scopes: (1) the airline industry, (2) websites and Internet services, (3) the tourism and hospitality industry, (4) the healthcare industry, (5) other transportation industries, (6) the manufacturing industry, (7) the banking sector, (8) the education sector, (9) service 
organisations, and (10) other areas (Table 11). According to the results provided in this table, previous studies used MCDM techniques and approaches for the airlines industry, which is the focus of 18 articles; website and Internet services - 16 articles; the tourism and hospitality industry -13 articles; the healthcare industry -7 articles; other transportation industries -5 articles; manufacturing industry -5 articles; banking, education and service industries -4 articles; and other areas -3 articles. In the next step, based on these classifications (10 application areas and scopes), all articles are presented in tables and each area of application is summarised based on the author, year, application area, technique and approach, the number of criteria, the study purpose, gap and research problem, results and outcome, and the best criteria in each article (Tables 1-10). In the following section, the articles are distributed based on techniques and application areas (Table 12 and Fig. 1). The next section shows nationalities of authors (Table 13) and the following section provides the distribution of articles by the year of publication (Fig. 2). The last section presents articles based on the distribution by journals (Table 14).

Table 11. Distribution of articles by the area of application and scope

\begin{tabular}{lcc}
\hline \multicolumn{1}{c}{ Area of application } & Frequently & Frequently percentage \\
\hline Airline industry & 18 & $22.78 \%$ \\
\hline Websites and internet services & 16 & $20.25 \%$ \\
\hline Tourism and hospitality industry & 13 & $16.46 \%$ \\
\hline Healthcare industry & 7 & $8.86 \%$ \\
\hline Other transportation industries & 5 & $6.33 \%$ \\
\hline Manufacturing industry & 5 & $6.33 \%$ \\
\hline Banking sector & 4 & $5.06 \%$ \\
\hline Education sector & 4 & $5.06 \%$ \\
\hline Service organisations & 4 & $5.06 \%$ \\
\hline Other areas & 3 & $3.80 \%$ \\
\hline Total & 79 & $100.00 \%$ \\
\hline
\end{tabular}

\section{Distribution of articles by techniques and approaches}

Based on results presented in Table 12, a total of 79 articles used these techniques and approaches: 16 studies used AHP and fuzzy AHP in various areas of the service quality evaluation. Based on these results, 11 studies used TOPSIS and fuzzy TOPSIS, 5 studies - VIKOR and fuzzy VIKOR; integrated techniques and approaches were used in 23 articles, DEMATEL and fuzzy DEMATEL - in 8 articles, and other techniques and approaches - in 16 articles. The summary of applications of the MCDM techniques is provided in Table 12. 
Table 12. Summary of articles: area of application and scope

\begin{tabular}{lcc}
\hline \multicolumn{1}{c}{ Area of application } & Frequently & Frequently percentage \\
\hline Integrated techniques and approaches & 23 & $29.11 \%$ \\
\hline AHP and Fuzzy AHP & 16 & $20.25 \%$ \\
\hline Other techniques and approaches & 16 & $20.25 \%$ \\
\hline TOPSIS and Fuzzy TOPSIS & 11 & $13.92 \%$ \\
\hline DEMATEL and Fuzzy DEMATEL & 8 & $10.13 \%$ \\
\hline VIKOR and Fuzzy VIKOR & 5 & $\mathrm{~h} 6.33 \%$ \\
\hline Total & 79 & $100.00 \%$ \\
\hline
\end{tabular}

\section{Distribution of articles by application areas and techniques}

In recent decades, research on MCDM continued and many areas of application were discovered. MCDM provides strong decision-making methods in domains where selection of the best alternative is highly complex. This particular study provides a detailed review of the main streams of considerations in MCDM theory and practice. The main purpose is to identify various MCDM techniques and approaches in several fields of the service quality evaluation and to suggest approaches that could be used most robustly and effectively to identify best alternatives. The MCDM method has been applied in many domains of the service quality evaluation. The MCDM method helps to choose best alternatives where many criteria exist; the best one can be obtained by analysing different scopes and weights of the criteria, and the selection of the optimal ones can be done using MCDM techniques and approaches. This survey provides a comprehensive view of the development of various methods of MCDM for evaluation of the service quality. In total, 79 papers were classified into 10 application areas: (1) the airline industry, (2) websites and Internet services, (3) the tourism and hospitality industry, (4) the healthcare industry, (5) other transportation industries, (6) the manufacturing industry, (7) the banking sector, (8) the education sector, (9) service organisations, and (10) other application areas. Regarding the MCDM techniques and approaches, this review article classified these techniques and methods into six groups including: (1) AHP and fuzzy AHP, (2) TOPSIS and fuzzy TOPSIS, (3) VIKOR and fuzzy VIKOR, (4) integrated techniques and approaches (5) DEMATEL and fuzzy DEMATEL and (6) other techniques and approaches. Application areas and techniques are provided in Figure 1.

\section{Distribution of papers by the nationality of authors}

Table 13 shows that authors from 15 nationalities and countries applied MCDM for the evaluation of the service quality in various areas of application. Most of the published papers were from Taiwan (56.96\%). However, findings of this paper indicate that Turkey, Republic of Korea and Iran have published papers on the service quality evaluation by using MCDM techniques and applications. Table 13 presents details regarding the nationality of authors. 


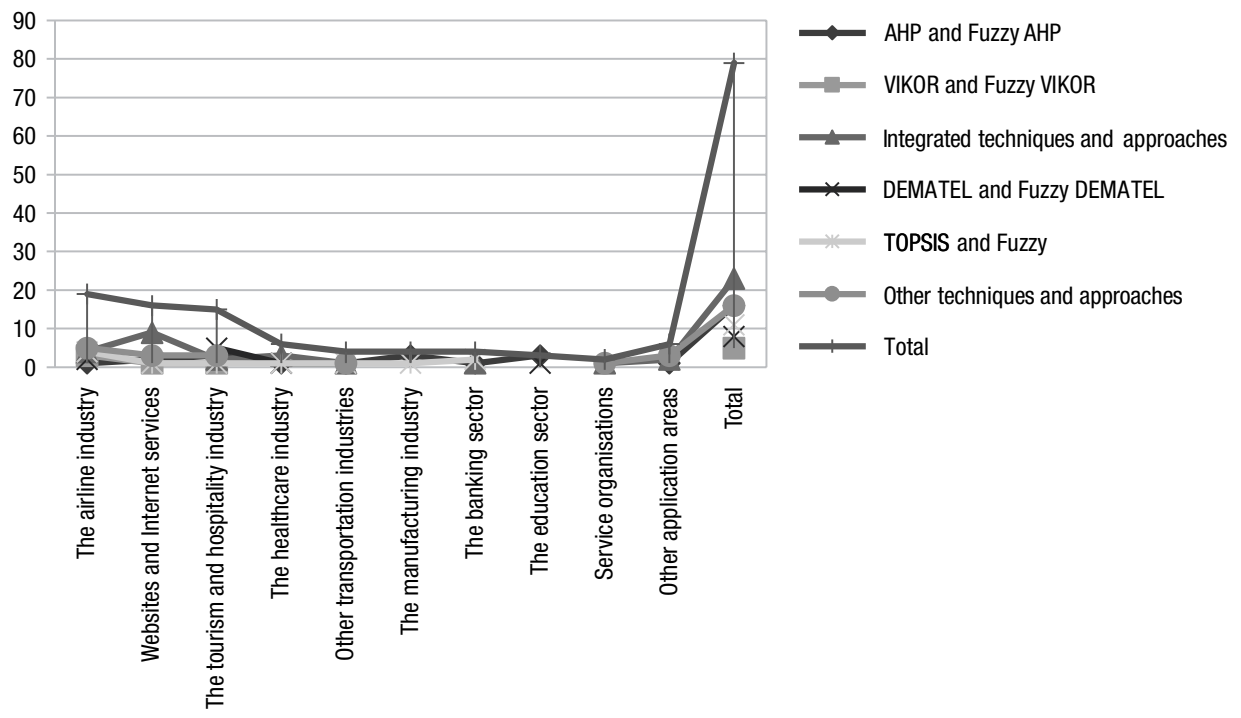

Fig. 1. Application areas and techniques

Table 13. Distribution of articles by the nationality of authors

\begin{tabular}{clcc}
\hline No. & \multicolumn{1}{c}{ Nationality } & Frequently & Frequently percentage \\
\hline 1 & Taiwan & 45 & $56.96 \%$ \\
\hline 2 & Turkey & 9 & $11.39 \%$ \\
\hline 3 & Republic of Korea & 4 & $5.06 \%$ \\
\hline 4 & Iran & 4 & $5.06 \%$ \\
\hline 5 & Malaysia & 3 & $3.80 \%$ \\
\hline 6 & Spain & 2 & $2.53 \%$ \\
\hline 7 & Italy & 2 & $2.53 \%$ \\
\hline 8 & China & 2 & $2.53 \%$ \\
\hline 9 & USA & 2 & $2.53 \%$ \\
\hline 10 & France & 1 & $1.27 \%$ \\
\hline 11 & Canada & 1 & $1.27 \%$ \\
\hline 12 & Serbia & 1 & $1.27 \%$ \\
\hline 13 & Greece & 1 & $1.27 \%$ \\
\hline 14 & Pakistan & 1 & $1.27 \%$ \\
\hline 15 & India & 1 & $1.27 \%$ \\
\hline
\end{tabular}

\section{Distribution of papers by the year of publication}

Figure 2 presents important evidence based on the frequency of distribution by the year of publication. The results indicate that from 2000 to 2015, information regarding the use of MCDM techniques and approaches for the evaluation of the service quality in various areas of the application has grown. According to the findings of this sec- 
tion, only one paper was found to have used these techniques and approaches in 2001. The number of such papers increased to six in 2006; and to 19 and 10 papers in 2011 and 2014, respectively. It can be indicated that currently, researchers of different fields related to the service quality evaluation used the MCDM techniques and approaches. Therefore, it can be predicted that in the coming years, these numbers will grow. Results regarding the year of publication are given in Figure 2.

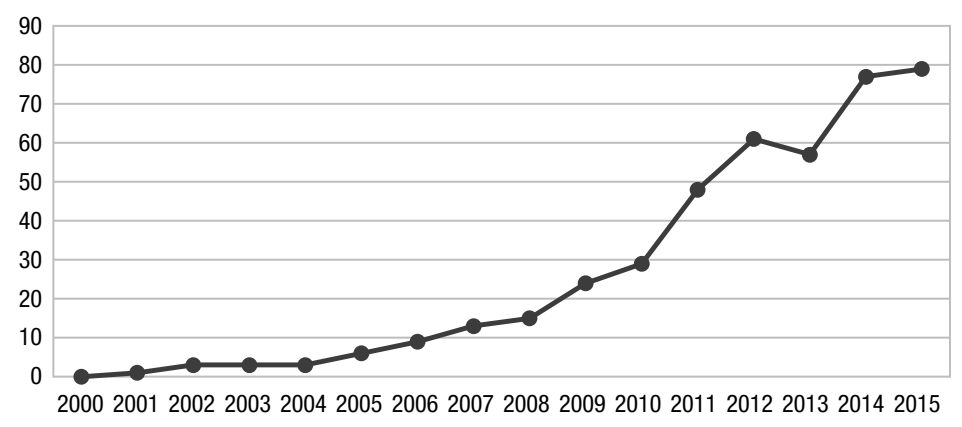

Fig. 2. Distribution of papers by the year of publication

\section{Distribution of papers by the name of the journal}

Table 14 provides the distribution by the name of the journal used fo this research. The papers related to the MCDM techniques and the service quality were found in 51 journals, which cover an extensive range of the "Web of Science, Scopus and Google Scholar" databases. From these 51 journals, the first and second rank were taken by the Applied Soft Computing and Expert Systems with Applications, which had seven papers. This result indicates that these two journals have a significant role in the area of MCDM issues and the evaluation of the service quality in various fields of application. IEEE journals had the third rank with six papers; in addition, the Journal of Tourism Management had four papers and was ranked the fourth. In other journal rankings, the Journal of Knowledge-Based Systems and the Journal of Air Transport Management had three papers and were ranked the fifth. The frequency of other published journals is shown in Table 14 and provides a list of journals with one used paper: the International Journal of Informatics and Communication Technology, the Journal of Islamic and Middle Eastern Finance and Management, Computers and Industrial Engineering, the Journal of Computer Science, the Journal of Information and Knowledge Management, Utilities Policy, the European Journal of Operational Research, Modeling Decisions for Artificial Intelligence, the Journal of the Chinese Institute of Industrial Engineers, the Journal of Information and Optimization Sciences, Expert Systems, Mathematical Problems in Engineering, the SIJ Transactions on Computer Science Engineering and its Applications, Technological and Economic Development of Economy, Online Information Review, Intelligent Decision Technologies, Library Management, Information and Control, Eskişehir Osmangazi Üniversitesi İktisadi ve İdari Bilimler Dergisi, Transportation Research Part E: Logistics and Transportation Review, the Journal of Services 
Marketing, Management Research and Practice, the International Journal of Electronic Business Management, the Service Industries Journal, the Journal of Convention and Event Tourism, Business and Economy, Transportation Research Part A: Policy and Practice, European Transport $\backslash$ Trasporti Europei, the Journal of Islamic Marketing, the Journal of Quality and Reliability Management, Embedded Software and Systems, the International Journal of Business Information Systems, JISTEM-Journal of Information Systems and Technology Management, the Journal of Mathematics and Computer Science, Quality and Quantity, Quality Assurance in Education, the International Journal of Computer Science and Engineering Technology (IJCSET), Industrial Engineering and Management Systems, the International Review of Management and Business Research, Computers in Human Behavior.

Table 14. Distribution of articles by the name of the journal

\begin{tabular}{clc}
\hline No. & \multicolumn{1}{c}{ Journal name } & Frequently \\
\hline 1 & Applied Soft Computing & 7 \\
\hline 2 & Expert Systems with Applications & 7 \\
\hline 3 & IEEE & 6 \\
\hline 4 & Tourism Management & 4 \\
\hline 5 & Journal of Air Transport Management & 3 \\
\hline 6 & Knowledge-Based Systems & 3 \\
\hline 7 & Total Quality Management and Business Excellence & 2 \\
\hline 8 & International Journal of Intelligent Systems & 2 \\
\hline 9 & Journal of Uncertainty, Fuzziness and Knowledge-based Systems & 2 \\
\hline 10 & International Journal of Computational Intelligence Systems & 2 \\
\hline 11 & Procedia-Social and Behavioral Sciences & 2 \\
\hline
\end{tabular}

\section{Conclusions}

This study aimed to review papers that used the MCDM techniques and approaches for the evaluation of the service quality in 10 different areas of application and that were published from 2000 to 2015 in 51 international journals accessible in popular databases such as Scopus, Web of Science and Google Scholar. Moreover, this study attempted to categorise these papers into 10 application areas and scopes: (1) the airline industry, (2) websites and Internet services, (3) the tourism and hospitality industry, (4) the healthcare industry, (5) other transportation industries, (6) the manufacturing industry, (7) the banking sector, (8) the education sector, (9) service organisations, and (10) other application areas. Results indicated that 18 papers used fuzzy and classic MCDM techniques and approaches in the airline industry. It was found that in relation to websites and Internet services, 16 studies used fuzzy and classic MCDM techniques and application. In the tourism and hospitality industry, 13 papers used fuzzy and classic 
MCDM techniques and application. While this type of study has never been conducted in the exact same way, the service quality and MCDM issues have been examined in a variety of industries over the last 10-20 years. This study only focused on those papers which have used MCDM techniques and approaches for the evaluation of the service quality in various industries and sectors such as airline, healthcare and tourism and hospitality industries, education and banking sectors, manufacturing and service industries and organisations and Internet website services. Future studies can be conducted on those articles that used other statistic's techniques and approaches, such as the Structural Equation Modeling (SEM). Results of this review article indicated that previous scholars focused more on the service quality evaluation in the airline industry rather than other industries, based on these research results, it can be observed that flight safety and security are the most important criteria.

Based on our findings, 16 studies used AHP and Fuzzy AHP. Some areas, in which previous studies used TOPSIS are airline, healthcare, tourism and hospitality industries, etc. In the distribution of journals, Applied Soft Computing and Expert Systems with Applications were given the first rank among 51 journals with seven published papers related to the MCDM issues. In the nationality-based classification, it was shown that 15 nationalities and countries applied MCDM to the evaluation of the service quality. Finally, Taiwan was shown to have the highest number of contributions to the publication of MCDM-related papers in the evaluation of the service quality. This review paper contributes to the existing literature by demonstrating the possibility of combining decision making and the evaluation of the service quality in the MCDM procedure. In an age of increasing globalisation and increasing flows of information, decision makers and scientists are trying to better understand how to construct decision-making systems to address a range of multi-level problems.

Results obtained from this review show that MCDM approaches and techniques are appropriate for the evaluation of the service quality. This study shows that a large number of MCDM approaches and techniques exists and many of these methods are applicable to the solution of problems related to the evaluation of the service quality. Each approach and technique may have some drawbacks and advantages, and it cannot be claimed that a particular approach or technique is more appropriate than the others. Various DMs generally disagree on the approach and technique, which is the most valid and suitable. The selection of an approach and technique is mostly dependent upon the preferences of DM and the analyst. The methods must be taken into consideration in terms of validity, suitability, and user-friendliness. In addition, it should be realized that employing different approaches and techniques will most likely lead to different recommendations, and it is noteworthy that there may be errors in any approach or technique. This paper provided several examples of ways, in which various MCDM approaches and techniques were applied in the evaluation of the service quality. By integrating the academic literature on the service quality and reviewing MCDM techniques and approaches in a variety of application areas, some insight into the specific results was gained, as well as a better understanding of the underlying dimensions of the service 
quality. The contributions of the study results to the existing literature on the service quality and MCDM issues were addressed and results were provided to academics scholars and leaders of organisations and industries in the field of service quality evaluation enabling them to improve their service processes by identifying relevant service quality attributes and assessing their impact on the service quality.

This particular paper has some limitations and recommendations for future studies. First of all, this study categorized 79 articles into 10 application areas and scopes, i.e., the airline industry, websites and Internet services, the tourism and hospitality industry, the healthcare industry, other transportation industries, the manufacturing industry, the banking sector, the education sector, service organisations, and other areas. It is recommended for future studies to review papers in different sub-areas of these categories. Articles published in late 2014 and 2015, if any, were not included in the paper due to the limitation of reporting time. A future review can be expanded. Another limitation is that the data were collected from journals, and the documents do not include papers, textbooks, doctoral and master's dissertations and theses, and unpublished papers on MCDM issues. As a result, in a future study, data can be collected from these sources, and the obtained results can be compared to the results obtained and reported in this study. The next limitation is that all of the papers were extracted from journals in English; then, the scholarly journals published in other languages were not included in this review. However, the researchers believed that this paper comprehensively reviewed and included most of the papers, which were published in international journals. The insights provided by this paper channel the research efforts and fulfill the needs of practitioners and researchers for an easy access to the fields of healthcare and the medical industry. This paper carefully selected and summarised the available papers of several publishers in Web of Science, Scopus, and Google Scholar. Though, a number of relevant outlets might have remained beyond the scope of the current study. Therefore, future studies could review the papers that were not used in the current review. As another limitation, the paper presents the review of numerous publications, which describe the use of MCDM recently-developed methods in journals. However, this review does not cover recent methods that have been published in books.

\section{References}

Abdullah, L.; Ling, H. M. 2012. Interval-valued intuitionistic fuzzy weighted entropy in evaluation of service quality, International Journal of Informatics and Communication Technology 2(1): 17-24. http://dx.doi.org/10.11591/ij-ict.v2i1.1525

Agnihothri, S.; Sivasubramaniam, N.; Simmons, D. 2002. Leveraging technology to improve field service, International Journal of Service Industry Management 13(1): 47-68.

http://dx.doi.org/10.1108/09564230210421155

Ahmad, A.; ur Rehman, K.; Saif, M. I. 2010. Islamic banking experience of Pakistan: comparison between Islamic and conventional banks, International Journal of Business and Management 5(2): 137. http://dx.doi.org/10.5539/ijbm.v5n2p137

Akdag, H.; Kalayc1, T.; Karagöz, S.; Zülfikar, H.; Giz, D. 2014. The evaluation of hospital service quality by fuzzy MCDM, Applied Soft Computing 23: 239-248.

http://dx.doi.org/10.1016/j.asoc.2014.06.033 
Altuntas, S.; Dereli, T.; Yilmaz, M. K. 2012. Multi-criteria decision making methods based weighted SERVQUAL scales to measure perceived service quality in hospitals: a case study from Turkey, Total Quality Management and Business Excellence 23(11-12): 1379-1395. http://dx.doi.org/10.1080/14783363.2012.661136

Aly, N.; Akpovi, J. 2001. Total quality management in California public higher education, Quality Assurance in Education 9(3): 127-131. http://dx.doi.org/10.1108/09684880110399077

Amirzadeh, R.; Reza Shoorvarzy, M. 2013. Prioritizing service quality factors in Iranian Islamic banking using a fuzzy approach, International Journal of Islamic and Middle Eastern Finance and Management 6(1): 64-78. http://dx.doi.org/10.1108/17538391311310752

Awasthi, A.; Chauhan, S. S.; Omrani, H.; Panahi, A. 2011. A hybrid approach based on SERVQUAL and fuzzy TOPSIS for evaluating transportation service quality, Computers and Industrial Engineering 61(3): 637-646. http://dx.doi.org/10.1016/j.cie.2011.04.019

Aydin, S.; Kahraman, C. 2012. Evaluation of e-commerce website quality using fuzzy multi-criteria decision making approach, IAENG International Journal of Computer Science 39(1): 64-70.

Basu, R.; Bhola, P. 2014. A framework to identify service quality determinants of IT enabled scalable ventures: a study from Indian context, Journal of Information and Knowledge Management 13(4), 1-14. http://dx.doi.org/10.1142/S0219649214500324

Benitez, J. M.; Martín, J. C.; Román, C. 2007. Using fuzzy number for measuring quality of service in the hotel industry, Tourism management 28(2): 544-555.

http://dx.doi.org/10.1016/j.tourman.2006.04.018

Bilsel, R. U.; Büyüközkan, G.; Ruan, D. 2006. A fuzzy preference-ranking model for a quality evaluation of hospital web sites, International Journal of Intelligent Systems 21(11): 1181-1197. http://dx.doi.org/10.1002/int.20177

Bogetoft, P.; Pruzan, P. 1997. Planning with multiple criteria: investigation, communication and choice, Journal of Multi-Criteria Decision Analysis 8(2): 112.

Bueyuekoezkan, G.; Ruan, D. 2007. Evaluating government websites based on a fuzzy multiple criteria decision-making approach, International Journal of Uncertainty Fuzziness and Knowledge-Based Systems 15(3): 321-343. http://dx.doi.org/10.1142/S0218488507004704

Büyüközkan, G.; Çifçi, G. 2012. A combined fuzzy AHP and fuzzy TOPSIS based strategic analysis of electronic service quality in healthcare industry, Expert Systems with Applications 39(3): 2341-2354. http://dx.doi.org/10.1016/j.eswa.2011.08.061

Büyüközkan, G.; Çifçi, G.; Güleryüz, S. 2011. Strategic analysis of healthcare service quality using fuzzy AHP methodology, Expert Systems with Applications 38(8): 9407-9424.

http://dx.doi.org/10.1016/j.eswa.2011.01.103

Carrasco, R. A.; Villar, P.; Hornos, M. J.; Herrera-Viedma, E. 2012. A linguistic multicriteria decision-making model applied to hotel service quality evaluation from web data sources, International Journal of Intelligent Systems 27(7): 704-731. http://dx.doi.org/10.1002/int.21546

Çelen, A.; Yalçın, N. 2012. Performance assessment of Turkish electricity distribution utilities: an application of combined FAHP/TOPSIS/DEA methodology to incorporate quality of service, Utilities Policy 23: 59-71. http://dx.doi.org/10.1016/j.jup.2012.05.003

Chang, S. J.; Hsiao, H.-C.; Huang, L.-H.; Chang, H. 2011. Taiwan quality indicator project and hospital productivity growth, Omega 39(1): 14-22. http://dx.doi.org/10.1016/j.omega.2010.01.006 Chang, T. H. 2014. Fuzzy VIKOR method: a case study of the hospital service evaluation in Taiwan, Information Sciences 271: 196-212. http://dx.doi.org/10.1016/j.ins.2014.02.118

Chang, Y. H.; Yeh, C.-H. 2002. A survey analysis of service quality for domestic airlines, European Journal of Operational Research 139(1): 166-177.

http://dx.doi.org/10.1016/S0377-2217(01)00148-5 
Chao, L.; Qing, L 2006. Fuzzy theory and AHP based manufacturing execution systems (MES) vendor service quality evaluation method study, IEEE International Conference on IEEE 764-769.

Chen, C. T.; Hung, W. Z.; Lin, K. H.; Cheng, H. L 2009. An evaluation model of service quality by applying linguistic TOPSIS method, IEEE/INFORMS International Conference on IEEE 335-340.

Chen, C. T. 2001. Applying linguistic decision-making method to deal with service quality evaluation problems, International Journal of Uncertainty, Fuzziness and Knowledge-Based Systems 9: 103-114. http://dx.doi.org/10.1142/S0218488501001022

Cheng, C. H.; Chang, J. R.; Ho, T. H.; Chen, A. P. 2005. Evaluating the airline service quality by fuzzy OWA operators, Modeling Decisions for Artificial Intelligence 3558: 77-88.

http://dx.doi.org/10.1007/11526018_9

Chiang, C.; Lee, C. C.; Tzeng, G. H. 2009. A non-additive model for the evaluation of portal website service quality, Journal of the Chinese Institute of Industrial Engineers 26(5): 355-366. http://dx.doi.org/10.1080/10170660909509150

Chiang, T. C.; Yu, F. J. 2011. Improving real estate broker service quality via TOPSIS and AHP, Journal of Information and Optimization Sciences 32(1): 93-107.

http://dx.doi.org/10.1080/02522667.2011.10700045

Chien-Chang, C. 2012. Evaluating the quality of airport service using the fuzzy multi-criteria decision-making method: a case study of Taiwanese airports, Expert Systems 29(3): 246-260. http://dx.doi.org/10.1111/j.1468-0394.2010.00574.x

Choi, C.; Kim, C.; Sung, N.; Park, Y. 2007. Evaluating the quality of service in mobile business based on fuzzy set theory, Fourth International Conference on IEEE 483-487.

Chou, C. C.; Ding, J. F. 2013. Application of an integrated model with MCDM and IPA to Evaluate the service quality of transshipment port, Mathematical Problems in Engineering 1-7. http://dx.doi.org/10.1155/2013/656757

Chou, C. C.; Liu, L. J., Huang, S.-F.; Yih, J. M.; Han, T. C. 2011. An evaluation of airline service quality using the fuzzy weighted SERVQUAL method, Applied Soft Computing 11(2): 2117-2128. http://dx.doi.org/10.1016/j.asoc.2010.07.010

Chou, W. C.; Cheng, Y. P. 2012. A hybrid fuzzy MCDM approach for evaluating website quality of professional accounting firms, Expert Systems with Applications 39(3): 2783-2793.

http://dx.doi.org/10.1016/j.eswa.2011.08.138

Chung, Y. F.; Liu, S.-H.; Wang, C.-H.; Pang, C.-T. 2015. Applying fuzzy MCDM methods to the evaluation on portal website service quality, The SIJ Transactions on Computer Science Engineering and its Applications 3(1): 8-15.

Dodgson, J.; Spackman, M.; Pearman, A.; Phillips, L. 2009. Multi-criteria analysis: a manual. Department for Communities and Local Government: London. Available from Internet: http:// eprints.lse.ac.uk/12761/

Ecer, F. 2014. A hybrid banking websites quality evaluation model using AHP and COPRAS-G: a Turkey case, Technological and Economic Development of Economy 20(4): 758-782. http://dx.doi.org/10.3846/20294913.2014.915596

Edelman, D. C. 2010. Branding in the digital age, Harvard business review 88(12): 62-69.

Elzinga, D.; Mulder, S.; Vetvik, O. J. 2009. The consumer decision journey, McKinsey Quarterly 3: $96-107$.

Ferreira, F. A. F.; Spahr, R. W.; Santos, S. P.; Rodrigues, P. M. 2012. A multiple criteria framework to evaluate bank branch potential attractiveness, International Journal of Strategic Property Management 16(3): 254-276. http://dx.doi.org/10.3846/1648715X.2012.707629 
Gerrard, P.; Cunningham, J. B. 2005. The service quality of e-banks: an exploratory study, International Journal of Financial services management 1(1): 102-117.

http://dx.doi.org/10.1504/IJFSM.2005.007987

Hsieh, L. F.; Lin, L. H.; Lin, Y. Y. 2008. A service quality measurement architecture for hot spring hotels in Taiwan, Tourism Management 29(3): 429-438.

http://dx.doi.org/10.1016/j.tourman.2007.05.009

Hsu, T.-H.; Hung, L. C.; Tang, J. W. 2012a. A hybrid ANP evaluation model for electronic service quality, Applied Soft Computing 12(1): 72-81. http://dx.doi.org/10.1016/j.asoc.2011.09.008 Hsu, T. H.; Hung, L. C.; Tang, J. W. 2012b. The multiple criteria and sub-criteria for electronic service quality evaluation: an interdependence perspective, Online Information Review 36(2): 241-260. http://dx.doi.org/10.1108/14684521211229057

Hu, Y. C. 2009. Fuzzy multiple-criteria decision making in the determination of critical criteria for assessing service quality of travel websites, Expert Systems with Applications 36(3): 64396445. http://dx.doi.org/10.1016/j.eswa.2008.07.046

$\mathrm{Hu}$, Y. C.; Liao, P. C. 2011. Finding critical criteria of evaluating electronic service quality of Internet banking using fuzzy multiple-criteria decision making, Applied Soft Computing 11(4): 3764-3770. http://dx.doi.org/10.1016/j.asoc.2011.02.008

Huang, C. Y.; Hsu, P. C.; Tzeng, G.-H. 2012. Evaluating cloud computing based telecommunications service quality enhancement by using a new hybrid MCDM model, Intelligent Decision Technologies 15: 519-536. http://dx.doi.org/10.1007/978-3-642-29977-3_52

Jamali, R.; Sayyadi Tooranloo, H. 2009. Prioritizing academic library service quality indicators using fuzzy approach: case study: libraries of Ferdowsi University, Library Management 30(4/5): 319-333. http://dx.doi.org/10.1108/01435120910957977

Jeng, D. J. F. 2012. Selection of an improvement strategy in internal service operations: the MCDM approach with fuzzy AHP and nonadditive fuzzy integral, International Journal of Innovative Computing, Information and Control 8(8): 5917-5933.

Jensen, J. B.; Markland, R. E. 1996. Improving the application of quality conformance tools in service firms, Journal of Services Marketing 10(1): 35-55.

http://dx.doi.org/10.1108/08876049610147838

Kaya, T. 2010. Multi-attribute evaluation of website quality in E-business using an integrated fuzzy AHP TOPSIS methodology, International Journal of Computational Intelligence Systems 3(3): 301-314. http://dx.doi.org/10.1080/18756891.2010.9727701

Kazançoğlu, Y.; Kazançoğlu, İ. 2013. Benchmarking service quality performance of airlines in Turkey, Eskişehir Osmangazi Üniversitesi İktisadi ve İdari Bilimler Dergisi 8(1): 59-91.

Kuo, M. S. 2011. A novel interval-valued fuzzy MCDM method for improving airlines' service quality in Chinese cross-strait airlines, Transportation Research Part E: Logistics and Transportation Review 47(6): 1177-1193. http://dx.doi.org/10.1016/j.tre.2011.05.007

Kuo, M. S.; Liang, G. S. 2011. Combining VIKOR with GRA techniques to evaluate service quality of airports under fuzzy environment, Expert Systems with Applications 38(3): 1304-1312. http://dx.doi.org/10.1016/j.eswa.2010.07.003

Laroche, M.; Mukherjee, A.; Nath, P. 2005. An empirical assessment of comparative approaches to service quality measurement, Journal of Services Marketing 19(3): 174-184.

http://dx.doi.org/10.1108/08876040510596858

Lassar, W. M.; Manolis, C.; Winsor, R. D. 2000. Service quality perspectives and satisfaction in private banking, Journal of Services Marketing 14(3): 244-271.

http://dx.doi.org/10.1108/08876040010327248

Lazim, A.; Wahab, N. 2010. A fuzzy decision making approach in evaluating ferry service quality, Management Research and Practice 2(1): 94-107. 
Lee, C. C.; Tzeng, G. H.; Chiang, C. 2011. Determining service quality measurement key indicators in a travel website using a fuzzy analytic hierarchy process, International Journal of Electronic Business Management 9(4): 322.

Lee, H.; Kim, C. 2012. A DEA-SERVQUAL approach to measurement and benchmarking of service quality, Procedia-Social and Behavioral Sciences 40: 756-762.

http://dx.doi.org/10.1016/j.sbspro.2012.03.262

Li, L. X. 1997. Relationships between determinants of hospital quality management and service quality performance - a path analytic model, Omega 25(5): 535-545.

http://dx.doi.org/10.1016/S0305-0483(97)00017-0

Lin, H. F. 2010. An application of fuzzy AHP for evaluating course website quality, Computers and Education 54(4): 877-888. http://dx.doi.org/10.1016/j.compedu.2009.09.017

Lin, C. L 2011. An integrated analysis of critical factor selection and service quality evaluation for shopping platform services, International Conference on, IEEE 691-696.

Lin, C. T.; Lin, C. W. 2013. Exhibitor perspectives of exhibition service quality, Journal of Convention and Event Tourism 14(4): 293-308. http://dx.doi.org/10.1080/15470148.2013.837020

Lin, C. T.; Lee, C.; Chen, W. Y. 2009a. Using fuzzy analytic hierarchy process to evaluate service performance of a travel intermediary, The Service Industries Journal 29(3): 281-296.

http://dx.doi.org/10.1080/02642060701846762

Lin, Z.; Wang, R.; Tseng, M. L. 2009b. Determination of a cause and effect decision making model for leisure farm's service quality in Taiwan, WSEAS Transactions on Business and Economics 6(2): 73-86

Liou, J. J. 2011. Variable Consistency Dominance-based Rough Set Approach to formulate airline service strategies, Applied Soft Computing 11(5): 4011-4020.

http://dx.doi.org/10.1016/j.asoc.2011.03.002

Liou, J. J.; Hsu, C. C.; Yeh, W. C.; Lin, R.-H. 2011a. Using a modified grey relation method for improving airline service quality, Tourism Management 32(6): 1381-1388.

http://dx.doi.org/10.1016/j.tourman.2011.01.013

Liou, J. J.; Tsai, C.Y.; Lin, R.-H.; Tzeng, G.-H. 2011b. A modified VIKOR multiple-criteria decision method for improving domestic airlines service quality, Journal of Air Transport Management 17(2): 57-61. http://dx.doi.org/10.1016/j.jairtraman.2010.03.004

Liou, J. J.; Tzeng, G. H. 2007. A non-additive model for evaluating airline service quality, Journal of Air Transport Management 13(3): 131-138. http://dx.doi.org/10.1016/j.jairtraman.2006.12.002

Liou, J. J. H.; Hsu, C. C.; Chen, Y.-S. 2014. Improving transportation service quality based on information fusion, Transportation Research Part A: Policy and Practice 67: 225-239.

http://dx.doi.org/10.1016/j.tra.2014.07.007

Lupo, T. 2013. Strategic analysis of transit service quality using fuzzy AHP methodology, European Transport/ Trasporti Europei 53:1-18.

Lupo, T. 2015. Fuzzy ServPerf model combined with ELECTRE III to comparatively evaluate service quality of international airports in Sicily, Journal of Air Transport Management 42: 249-259. http://dx.doi.org/10.1016/j.jairtraman.2014.11.006

Min, H.; Mitra, A.; Oswald, S. 1997. Competitive benchmarking of health care quality using the analytic hierarchy process: an example from Korean cancer clinics, Socio-economic Planning Sciences 31(2): 147-159. http://dx.doi.org/10.1016/S0038-0121(96)00021-3

Muhammad Awan, H.; Shahzad Bukhari, K.; Iqbal, A. 2011. Service quality and customer satisfaction in the banking sector: a comparative study of conventional and Islamic banks in Pakistan, Journal of Islamic Marketing 2(3): 203-224. http://dx.doi.org/10.1108/17590831111164750 
Nejati, M.; Nejati, M.; Shafaei, A. 2009. Ranking airlines’ service quality factors using a fuzzy approach: study of the Iranian society, International Journal of Quality and Reliability Management 26(3): 247-260. http://dx.doi.org/10.1108/02656710910936726

Ozment, J.; Morash, E. A. 1994. The augmented service offering for perceived and actual service quality, Journal of the Academy of Marketing Science 22(4): 352-363.

http://dx.doi.org/10.1177/0092070394224004

Rhoades, D. L.; Waguespack Jr, B. 2008. Twenty years of service quality performance in the US airline industry, Managing Service Quality: An International Journal 18(1): 20-33.

Rust, R. T.; Oliver, R. L. 1993. Service quality: New directions in theory and practice: Sage Publications.

Seo, Y.J.; Jeong, H. Y.; Song, Y.-J. 2005. Best Web service selection based on the decision making between QoS criteria of service. Embedded Software and Systems. Springer.

Shahin, A.; Khazaei Pool, J.; Poormostafa, M. 2014. Evaluating and ranking hotels offering eservice by integrated approach of Webqual and fuzzy AHP, International Journal of Business Information Systems 15(1): 84-104. http://dx.doi.org/10.1504/IJBIS.2014.057966

Shee, D. Y.; Wang, Y. S. 2008. Multi-criteria evaluation of the web-based e-learning system: a methodology based on learner satisfaction and its applications, Computers and Education 50(3): 894-905. http://dx.doi.org/10.1016/j.compedu.2006.09.005

Shieh, J. I.; Wu, H.-H.; Huang, K. K. 2010. A DEMATEL method in identifying key success factors of hospital service quality, Knowledge-Based Systems 23(3): 277-282.

http://dx.doi.org/10.1016/j.knosys.2010.01.013

So, S. H.; Kim, J.; Cheong, K.; Cho, G. 2006. Evaluating the service quality of third-party logistics service providers using the analytic hierarchy process, Journal of Information Systems and Technology Management 3(3): 261-270. http://dx.doi.org/10.4301/S1807-17752006000300001

Souiden, N.; Pons, F. 2009. Product recall crisis management: the impact on manufacturer's image, consumer loyalty and purchase intention, Journal of Product and Brand Management 18(2):106-114. http://dx.doi.org/10.1108/10610420910949004

Teng, C. I.; Ing, C.-K.; Chang, H. Y.; Chung, K. P. 2007. Development of service quality scale for surgical hospitalization, Journal of the Formosan Medical Association 106(6): 475-484. http://dx.doi.org/10.1016/S0929-6646(09)60297-7

Toosi, N. M.; Kohanali, R. A. 2011. The study of airline service quality in the Qeshm free zone by fuzzy logic, Journal of Mathematics and Computer Science 2(1): 171-185.

Tsai, M. T.; Wu, H. L.; Liang, W. K. 2008. Fuzzy decision making for market positioning and developing strategy for improving service quality in department stores, Quality and Quantity 42(3): 303-319. http://dx.doi.org/10.1007/s11135-006-9047-1

Tsai, W. H.; Hsu, W.; Chou, W. C. 2011. A gap analysis model for improving airport service quality, Total Quality Management and Business Excellence 22(10): 1025-1040.

http://dx.doi.org/10.1080/14783363.2011.611326

Tsaur, S. H.; Chang, T. Y.; Yen, C. H. 2002. The evaluation of airline service quality by fuzzy MCDM, Tourism Management 23(2): 107-115. http://dx.doi.org/10.1016/S0261-5177(01)00050-4

Tseng, M. L. 2009a. A causal and effect decision making model of service quality expectation using grey-fuzzy DEMATEL approach, Expert Systems with Applications 36(4): 7738-7748. http://dx.doi.org/10.1016/j.eswa.2008.09.011

Tseng, M. L. 2009b. Using the extension of DEMATEL to integrate hotel service quality perceptions into a cause-effect model in uncertainty, Expert Systems with Applications 36(5): 90159023. http://dx.doi.org/10.1016/j.eswa.2008.12.052 
Tseng, M. L. 2011. Using hybrid MCDM to evaluate the service quality expectation in linguistic preference, Applied Soft Computing 11(8): 4551-4562.

http://dx.doi.org/10.1016/j.asoc.2011.08.011

Tseng, M. L.; Chen, Y. H.; Geng, Y. 2012. Integrated model of hot spring service quality perceptions under uncertainty, Applied Soft Computing 12(8): 2352-2361.

http://dx.doi.org/10.1016/j.asoc.2012.03.044

Tsinidou, M.; Gerogiannis, V.; Fitsilis, P. 2010. Evaluation of the factors that determine quality in higher education: an empirical study, Quality Assurance in Education 18(3): 227-244.

http://dx.doi.org/10.1108/09684881011058669

Tu, H. J.; Chao, Y. T. 2010. Toward a framework for assessing e-marketplace service quality, in Web Information Systems Engineering. Springer 36-43.

Wang, C.-H.; Pang, C.-T. 2011. Using VIKOR method for evaluating service quality of online auction under fuzzy environment, IJCSET 1(6): 307-314.

Wang, R. 2014. Beyond the Quality of Service, Industrial Engineering and Management Systems 13(2): 221-230. http://dx.doi.org/10.7232/iems.2014.13.2.221

Wang, R.; Lin, Y. H.; Tseng, M.-L. 2011. Evaluation of customer perceptions on airline service quality in uncertainty, Procedia-Social and Behavioral Sciences 25: 419-437.

http://dx.doi.org/10.7232/iems.2014.13.2.221

Wu, C.; Wang, R. 2014. Evaluating Chinese Tourists' service quality criteria under uncertainty, International Review of Management and Business Research 3(2): 858-868.

Wu, Y. C. J.; Shen, J. P.; Chang, C. L. 2014. Electronic service quality of Facebook social commerce and collaborative learning, Computers in Human Behavior 51: 1395-1402.

http://dx.doi.org/10.1016/j.chb.2014.10.001

Yedla, S.; Shrestha, R. M. 2003. Multi-criteria approach for the selection of alternative options for environmentally sustainable transport system in Delhi, Transportation Research Part A: Policy and Practice 37(8): 717-729. http://dx.doi.org/10.1016/S0965-8564(03)00027-2

Yeh, C. H. Deng, H.; Chang, Y. H. 2000. Fuzzy multicriteria analysis for performance evaluation of bus companies, European Journal of Operational Research 126(3): 459-473.

http://dx.doi.org/10.1016/S0377-2217(99)00315-X

Zavadskas, E. K.; Turskis, Z. 2011. Multiple criteria decision making (MCDM) methods in economics: an overview, Technological and Economic Development of Economy 17(2): 397-427. http://dx.doi.org/10.3846/20294913.2011.593291

Zineldin, M. 2002. Managing in the@ age: Banking service quality and strategic positioning, Measuring Business Excellence 6(4): 38-43. http://dx.doi.org/10.1108/13683040210451705 
Abbas MARDANI PhD at the Faculty of Management, Universiti Teknologi Malaysia (UTM). He received his PhD from Universiti Teknologi Malaysia (UTM), the Bachelor's Degree in Industrial Management and the Master's Degree in Industrial Management, the field of Operation and Production Management in Iran. His current research interests focus on areas of operation and production management, Multiple Criteria Decision Making (MCDM), Fuzzy Set Theory, renewable and sustainable energy.

Ahmad JUSOH is Research Manager and Senior Lecturer $(\mathrm{PhD})$ at the Faculty of Management, Universiti Teknologi Malaysia (UTM); He received his Bachelor's Degree in Technology Management from Universiti Teknologi Malaysia (UTM), his Master's Degree in Science (Quality and Productivity Improvement) from Universiti Kebangsaan Malaysia (UKM) and his PhD of Quality Management from Universiti Utara Malaysia (UUM). His current research interests focus on business statistics, production and operation management, system quality, Total Quality Management, engineering management and multiple criteria decision making (MCDM).

Edmundas Kazimieras ZAVADSKAS is PhD, DSc, Dr. h.c. mult. Prof., Head of the Department of Construction Technology and Management at Vilnius Gediminas Technical University, Lithuania. Editor-in-Chief of the journal of Technological and Economic Development of Economy (IF: 2.818) and the Journal of Civil Engineering and Management (IF: 1.372), Taylor \& Francis Journals. He is Senior Research Fellow at the Researcher of Research Institute of Smart Building Technologies. He is a member of the Lithuanian and several foreign Academies of Sciences. His current research interests focus on areas of building technology and management, Decision-Making Theory, decision support systems, Multiple Criteria Decision Making (MCDM).

Zainab KHALIFAH is Dean and Professor $(\mathrm{PhD})$ at the Faculty of Management, Universiti Teknologi Malaysia (UTM). She received her PhD in the field of Tourism Management, University of Strathclyde, Glasgow, Scotland, UK (1997). She received her Bachelor's (1983) and Master's (1985) degrees in Economic and Applied Economics from the Northern Illinois University, De Kalb, Illinois, USA. Her current research interests focus on areas of operation and production management, service quality, tourism and hospitality management.

Khalil MD NOR is Deputy Dean (Academic) and Professor at the Faculty of Management, Universiti Teknologi Malaysia (UTM). He received his PhD (Business Administration) at the Southern Illinois University in Carbondale, Illinois, USA. He received his Bachelor's Degree (Economics and Industrial Management) and Master's Degree (Public Management and Policy) from Carnegie Mellon in Pittsburgh, Pennsylvania, USA. His current research interests focus on technology acceptance, strategic information system, e-commerce, knowledge management and service quality. 